\title{
Synthesis of novel molecular probes inspired by harringtonolide
}

\author{
Vinayak Hegde, ${ }^{a}$ Marc Campitelli, ${ }^{a}$ Ronald J. Quinn ${ }^{a}$ and David Camp* ${ }^{* a}$ \\ Received (in $X X X, X X X)$ Xth $X X X X X X X X X 200 X$, Accepted Xth $X X X X X X X X X 200 X$ \\ First published on the web $X t h X X X X X X X X X 200 X$ \\ ${ }_{5}$ DOI: 10.1039/b000000x
}

A novel harringtonolide-inspired scaffold containing a cycloheptatriene ring and two fused cyclopentane rings has been synthesised from simple starting materials. The scaffold, containing a similar substitution pattern and relative stereochemistry to the complex diterpenoid, has been enumerated into a small library of derivatives. One of these library members has been converted 10 into a sub-library of substituted triazoles using copper-catalysed azide-alkyne cycloaddition (click) chemistry. The scaffold may be useful in drug discovery or in the preparation of additional molecular probes for chemical biology.

\section{Introduction}

Small molecules are critical tools for understanding important 15 cellular events and biological pathways involved in health and disease. The identification of new structural classes is one of the many drivers en route to understanding biological systems and developing innovative, safer therapeutics with novel modes of action. This is a truly daunting task given there are 20 in excess of an estimated $10^{62}$ drug-like molecules with a molecular weight below 500 Da comprised of the atoms that make up current small molecule therapies. ${ }^{1}$ Indeed, it would be impossible to synthesize even one molecule of each member from this set considering there is estimated to be 25 'only' $10^{50}$ atoms on Earth. ${ }^{2}$ Various strategies that attempt to address the relationship between chemistry and biology space have been developed in an effort to meet this challenge.

One popular approach, particularly within the pharmaceutical industry, has been to exploit 'privileged' 30 structures with known drug-like properties. ${ }^{3}$ The term was originally introduced to describe motifs that could be elaborated into libraries of drug-like molecules (ligands) in which different members could selectively and potently interact with a variety of unrelated biological targets. ${ }^{4,5}$

35 Harringtonolide 1 was first isolated from the seeds of the yew species Cephalotaxus harringtonia (Taxaceae) and shown to inhibit plant growth in tobacco and beans. ${ }^{6}$ Soon after, 1 was independently discovered in the bark of the related Chinese species, Cephalotaxus hainanensis, and found to be 40 active against Lewis lung carcinoma, Walker carcinoma, Sarcoma-180 and L-1210, L-615 and P-388 leukemias. ${ }^{7}$ It has also exhibited in vitro activity against influenza type A, Newcastle disease, Japanese B encephalitis and vaccinia viruses. ${ }^{8}$ The breadth of biological activity that spans plant 45 and human health attributed to $\mathbf{1}$ suggests that it may contain a privileged substructure.

Interestingly, homoharringtonine $\mathbf{2}$, which is currently in phase II/III trials for chronic myeloid leukemia, ${ }^{9}$ is produced by the same species while $\mathrm{Taxol}^{\circledR} \mathbf{3}$, an FDA approved drug 50 for various cancers, ${ }^{10}$ was originally isolated from another member of the Taxaceae family, Taxus brevifolia (Fig. 1). ${ }^{11}$
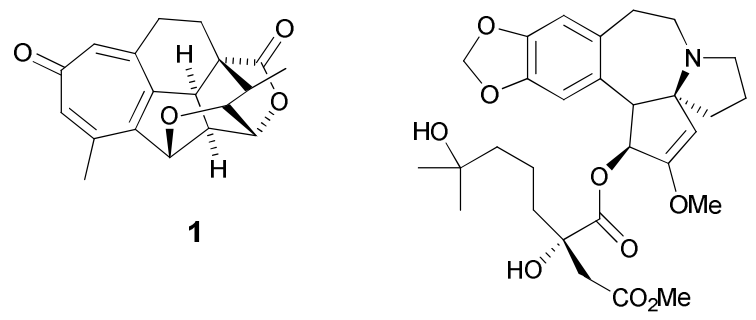

2

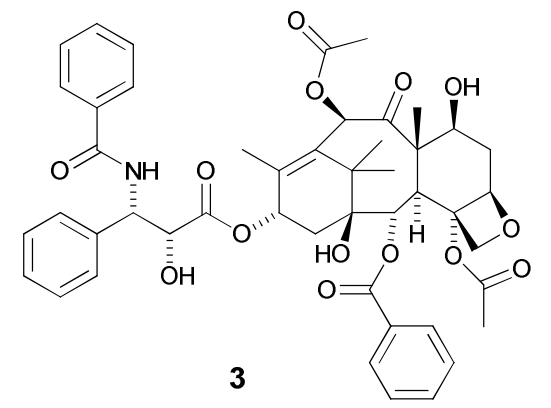

Fig. 1 Bioactive molecules isolated from the Taxaceae family.

\section{${ }_{55}$ Results and discussion}

Scaffolds 4 and 5 were initially selected for synthesis (Scheme 1) because of the unusual 5-6-7 fused tricyclic substructure embedded in harringtonolide. Scaffold 4 incorporates the tropone moiety of $\mathbf{1}$ while $\mathbf{5}$ is the 60 methoxycycloheptatriene analogue. We also saw tactical value in preparing a second scaffold inspired by the natural product that could afford a library of closely related structural analogues. Ideally, such a motif would be novel, derived from readily available starting materials and synthesized via the 65 same reaction sequence as that of $\mathbf{4}$ and $\mathbf{5}$.

The 5-5-7 fused tricyclic framework in 6 and 7 has not previously been reported, which was somewhat surprising given that fused seven-member ring systems are found in an increasing number of natural products of interest to the 70 biological and pharmaceutical communities. ${ }^{12,13}$ For example, it has recently been proposed that the 5-7-5 lactone ring system found in helenalin, parthenin and chinensiolide B 
should be regarded as a privileged scaffold due to the diverse biological activity exhibited by these compounds. ${ }^{14} \mathrm{We}$ therefore pursued the syntheis of the 5-5-7 tricycle on account of the novel carbon skeleton containing a highly desirable 5-7

5 fused ring system.

Positioning of the methoxy group gamma to the carbonyl and use of a 5-membered ring in the starting material (Scheme 2) was also reasoned to provide sufficient variation in the key intermediate and related downstream products so as to 10 ameliorate any potential stability issues that may be encountered with the series based on the natural product. ${ }^{15}$<smiles>[R6]C1C[C@H]2CCCc3ccc(=O)cc1c32</smiles>

4<smiles>[R6]C1C[C@H]2CCc3ccc(=O)cc1c32</smiles>

6<smiles>[R9]C1C[C@H]2CCCC3=C2C1=CCC(OC)=C3</smiles>

5

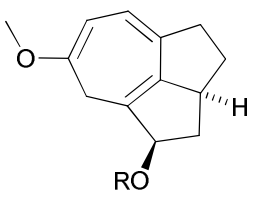

7
Fig. 2 Scaffolds 4 and 5 incorporating the 5-6-7 tricycle of harringtonolide and scaffolds 6 and 7 containing a 5-5-7 motif inspired by 15 the natural product.

The methoxycycloheptatriene motif in $\mathbf{5}$ and $\mathbf{7}$ would clearly have a different electron density to the tropone substructure of $\mathbf{4}$ and $\mathbf{6}$. Thus, libraries based on $\mathbf{5}$ and $\mathbf{7}$ would not be expected to mimic binding of the tropone moiety

20 in the natural product. However, we considered the synthesis of 5 and 7 to nevertheless be important from the perspective of being able to generate novel probe libraries that may afford valuable SAR insights. In this sense, our objective was not necessarily to produce scaffolds derived directly from the 25 natural product but rather explore the chemistry of similarly substituted analogues based on, or inspired by, the unusual carbon framework of $\mathbf{1}$.

An overlay of the most dissimilar scaffolds, 4 and $7(\mathrm{R}=$ $\mathrm{CH}_{3}$ ), as shown in Fig. 3 reveals that the 5-5-7 system 30 inspired by the natural product closely approximates the 5-6-7 assembly in terms of placement of the oxygen atoms relative to each other. Additionally, Scitegic ${ }^{\circledR}$ EPFP4 fingerprints generated from Bennis and Murko molecular framework representations were compared using the Tanimoto coefficient ${ }_{35}(\mathrm{Tc}) .{ }^{16}$ The calculated Tc of 0.74 between scaffolds 4 and 7 (R $=\mathrm{H})$ indicates that the 5-6-7 and 5-5-7 scaffolds are within the commonly used heuristic $(\geq 0.7)$ for clustering similar chemical structures. ${ }^{17}$

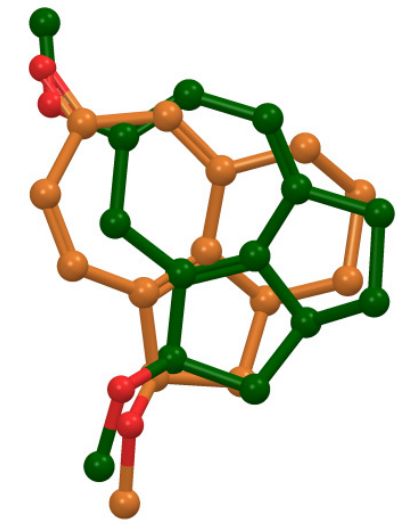

Fig. 3 Overlay of the natural product 5-6-7 substructure, 4, shown in orange and the 5-5-7 series scaffold of 7 shown in green.

Our synthetic strategy for the preparation of scaffolds 4 - 7 45 was guided by model studies involving intramolecular cyclopropanation of a benzenoid synthon described by Mander and co-workers en route towards the first total synthesis of $\mathbf{1}^{18,19}$ Scheme 1 outlines the synthesis of intermediates $8-12$ to construct the 5-6-7 framework found 50 in the natural product while Scheme 2 summarises the synthesis of analogues $\mathbf{1 3}-\mathbf{1 7}$ leading to the 5-5-7 tricycle.<smiles>CCOC(=O)C=C1CCCc2cc(OC)ccc21</smiles><smiles>COc1ccc2c(c1)CCCC2CC(=O)O</smiles><smiles>CCOC(=O)CC1CCCc2cc(OC)ccc21</smiles>

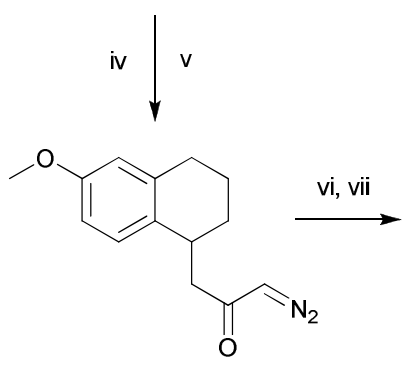

11

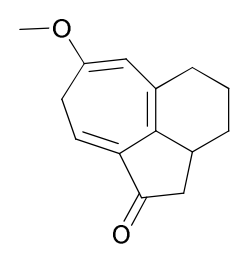

12
Scheme 1 Synthesis of the key intermediate 12 for scaffolds based on the 55 5-6-7 ring system embedded in harringtonolide. 


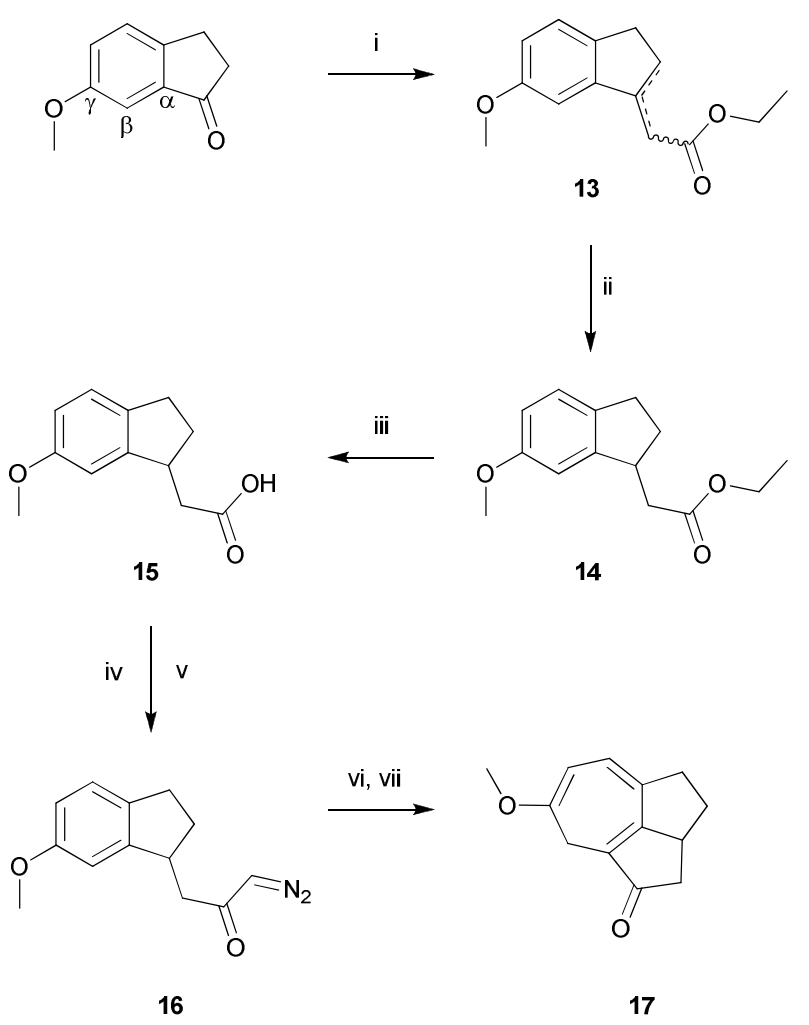

Scheme 2 Synthesis of the key intermediate $\mathbf{1 7}$ for scaffolds based on the 5-5-7 inspired by harringtonolide.

Table 1 Reaction conditions and yields en route to the key intermediates 512 and 17

\begin{tabular}{|c|c|c|c|}
\hline \multirow[t]{2}{*}{ step } & \multirow[t]{2}{*}{ conditions } & \multicolumn{2}{|c|}{ yield (\%) } \\
\hline & & 5-6-7 series & 5-5-7 series \\
\hline i & 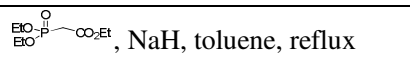 & $64^{20}$ & $72^{21}$ \\
\hline ii & $\mathrm{Pd} / \mathrm{C}, \mathrm{H}_{2}$, ethanol, $50^{\circ} \mathrm{C}, 5 \mathrm{~h}$ & $91^{20}$ & $98^{21}$ \\
\hline iii & $1 \mathrm{M} \mathrm{NaOH}$, aq. $\mathrm{MeOH}, 20^{\circ} \mathrm{C}$ & 98 & 98 \\
\hline iv & Oxalyl chloride, DMF, $-20^{\circ} \mathrm{C}, 2 \mathrm{~h}^{a}$ & & \\
\hline $\mathrm{v}$ & Diazomethane, ether, $0^{\circ} \mathrm{C}$ & $90^{b}$ & $85^{b}$ \\
\hline vi & Copper (II) ethylacetoacetate & & \\
\hline vii & $\mathrm{DBU}$ & $52^{b}$ & $75^{b}$ \\
\hline
\end{tabular}

${ }^{a}$ A temperature of $-10{ }^{\circ} \mathrm{C}$ was used for the 5-5-7 series . ${ }^{b}$ Overall yield when combined with previous step.

Generally, more care or longer reaction times were 10 necessary for the 5-6-7 series but, overall, production of $\mathbf{1 2}$ and 17 proceeded smoothly in fair to excellent yield (Table1). Rhodium acetate was also investigated in the critical reaction to install the cycloheptatriene ring in an effort to improve yields. However, product formation for both series was 15 typically $10 \%$ lower than with the copper catalyst in our hands.

Mander's report ${ }^{15}$ that the tropone derived directly from the key intermediate 12, i.e. 18, was unstable influenced the planning of the next stage of our synthesis. Library 20 enumeration would proceed via the scaffolds 19 and $20 a$ derived from reduction of the carbonyl group on the key ketocycloheptatriene intermediates, $\mathbf{1 2}$ and $\mathbf{1 7}$ respectively, and not from reduction of the same group via the tropones.

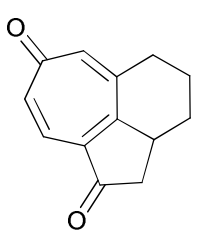

18

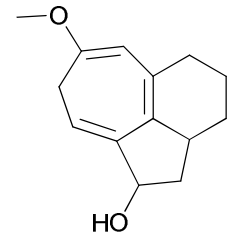

19
25 Unfortunately, in the case of the 5-6-7 series, any further manipulation of $\mathbf{1 2}$ proved futile as the ensuing products were unstable and either decomposed upon standing or further reaction immediately following purification. Indeed, while $\mathbf{1 2}$ could be obtained as a white powder following 30 chromatography, it gradually turned grey over 2-3 days despite being stored in the dark at $4{ }^{\circ} \mathrm{C}$. Attempted reduction of the ketone functionality with $\mathrm{NaBH}_{4}$ yielded the unstable alcohol 19 which decomposed completely following reaction of freshly purified material with different benzyl bromides.

35 In an effort to retrieve this series, we converted $\mathbf{1 2}$ to $\mathbf{1 8}$ despite reservations about proceeding via the tropone. While the crude tropone was produced in reasonable yield, it decomposed during purification on silica or upon storage in the dark at $4{ }^{\circ} \mathrm{C}$ thus obviating reduction of the ketone on the 40 five-membered ring to afford $4(\mathrm{R}=\mathrm{H})$ and effectively extinguishing this route for subsequent enumeration.

It was therefore heartening to observe that the closely related 17 was not only obtained in improved yield following the crucial cyclopropanation step but was also considerably 45 more stable than 12. The ketocycloheptatriene 17 could readily be converted to a mixture of syn and anti alcohols, 20a and 20b, in a diastereomeric ratio of 95:5 respectively, and near quantitative yield using $\mathrm{NaBH}_{4}$. Both alcohols are stable at room temperature, unlike the corresponding analogues in 50 the 5-6-7 series.

The relative stereochemistry of each isomer was established by ROESY NMR spectroscopy. A through-space interaction was observed between the $\mathrm{C} 1$ and $\mathrm{C} 2 \mathrm{a}$ protons in $\mathrm{CDCl}_{3}$ of the major product (Fig. 4) but not the minor adduct. 55 Unfortunately, the hydroxyl proton signal for both the syn and anti adducts was not apparent in $\mathrm{CDCl}_{3}$ so that any additional correlations supporting the relative stereochemistry of each isomer was not possible. However, changing the solvent to acetone- $\mathrm{D}_{6}$ allowed the hydroxyl proton signals for the syn 60 and anti isomers to be observed as doublets at $\delta_{\mathrm{H}} 3.91$ and $3.66 \mathrm{ppm}$ respectively. This facilitated detection of a throughspace interaction between the $\mathrm{H}$ atoms attached to the hydroxyl oxygen and $\mathrm{C} 2 \mathrm{a}$ in the case of the minor anti isomer 20b only. Importantly, the ROESY NMR experiments ${ }_{65}$ established that the major product had the same relative stereochemistry as harringtonolide's fused 5-7 substructure. 


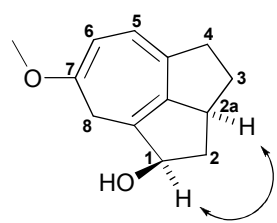

$20 a$

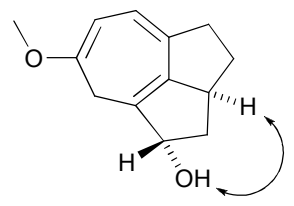

20b
Fig. 4 Syn (20a) and anti (20b) adducts obtained following reaction of 17 with $\mathrm{NaBH}_{4}$. ROESY correlations specific to each isomer are shown.

The syn adduct is presumably favored because of steric 5 approach control. This occurs when delivery of hydride takes place from the same face as the hydrogen atom on $\mathrm{C} 2 \mathrm{a}$. The syn isomers were not resolved into their enantiomers as we considered the racemic compound adequate for the purposes of a probe/lead generation library.

10 Having successfully generated scaffold 20a, we next set about converting it into a library of probe molecules. Thus, 20a was reacted further with a selection of benzyl-, alkyl-, and propargyl bromides to afford the corresponding ethers 21a-f in moderate to good yields (Table 2).

15 Table 2 Reaction conditions and yields of ethers 21 a-f

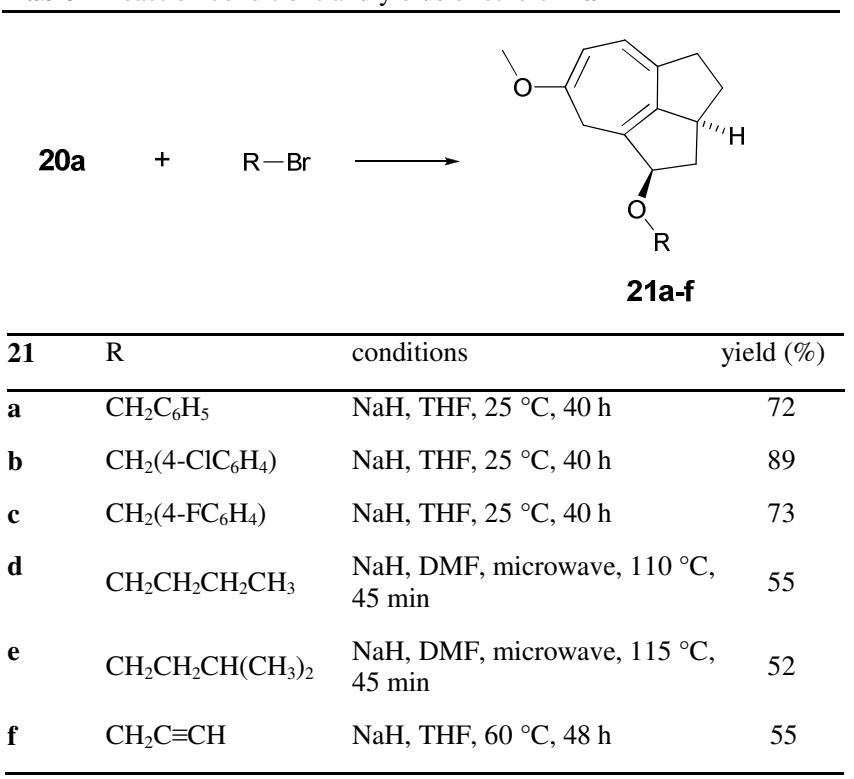

The propargyl ether $21 \mathbf{f}$ was subsequently converted into a sub-library of substituted triazoles using copper-catalysed azide-alkyne cycloaddition (click) chemistry. Thus, reaction 20 of benzylazide 22, derived from the reaction of benzyl bromide with $\mathrm{NaN}_{3}$, under standard click chemistry reaction conditions afforded the triazole 23a in good yield with the expected regioselectivity $^{22}$ (Scheme 3, Table 3). Preparation of the corresponding alkyl azides from $n$-butyl and $i$-pentyl 25 bromides was more problematic, most likely due to their low boiling points which hampered isolation, and necessitated use of a modified method to prepare the triazoles. Employing a one-pot, three-component microwave-assisted procedure directly afforded 23b-c with exclusive formation of the 1,430 disubstituted regioisomer in reasonable yield (Scheme 3, Table 3). ${ }^{23}$
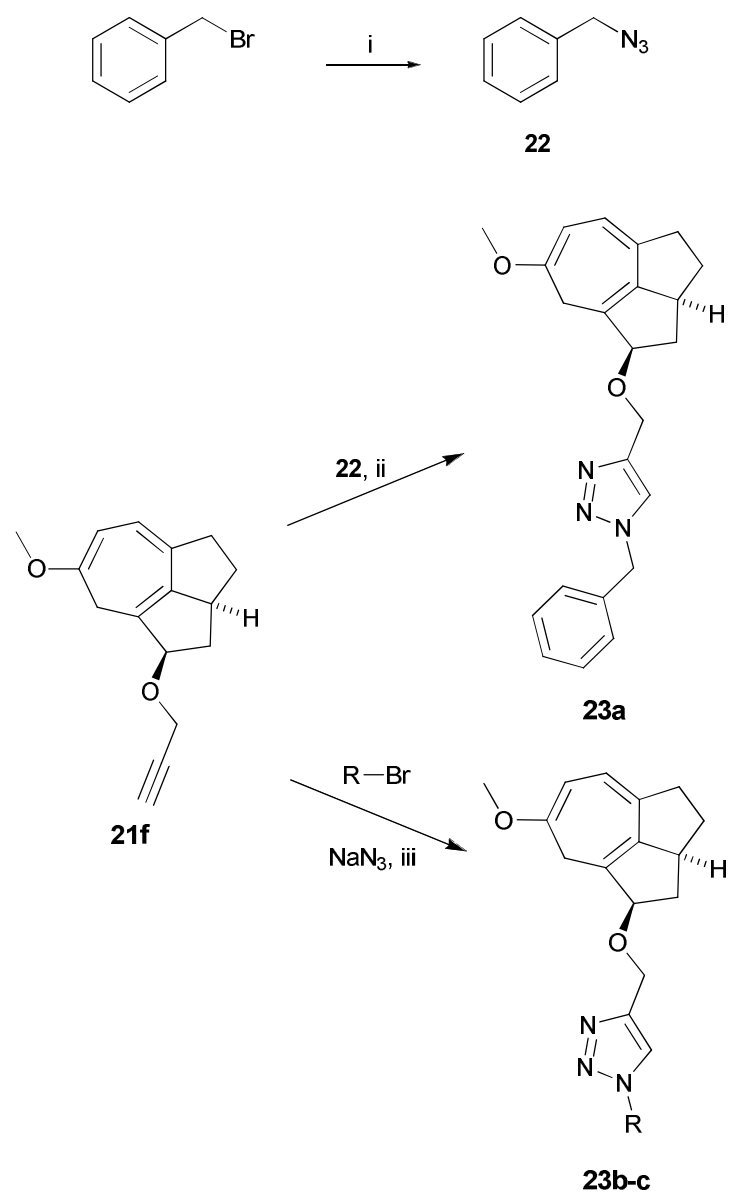

Scheme 3 Synthesis of triazoles 23a-c from benzyl-, $n$-butyl- and $i$-pentyl bromide starting materials and 21 using two-step (23a) and one-pot 35 three-component procedure (23b-c).

Table 3 Reaction conditions and yields of triazoles 23a-c

\begin{tabular}{lllc}
23 & $\mathrm{R}$ & conditions & yield (\%) \\
\hline a & $\mathrm{CH}_{2} \mathrm{C}_{6} \mathrm{H}_{5}$ & $\begin{array}{l}\text { (i) } \mathrm{NaN}_{3}, \mathrm{DMF}, 25{ }^{\circ} \mathrm{C}, 12 \mathrm{~h} \\
\text { (ii) } t \text { - } \mathrm{BuOH} / \mathrm{H}_{2} \mathrm{O}, \mathrm{CuSO}_{4}, \\
\end{array}$ & $85^{a}$ \\
sodium ascorbate, $25^{\circ} \mathrm{C}, 16 \mathrm{~h}$ & 60 \\
b $\mathrm{CH}_{2} \mathrm{CH}_{2} \mathrm{CH}_{2} \mathrm{CH}_{3}$ & $\begin{array}{l}\text { (iii) } t \text { - } \mathrm{BuOH} / \mathrm{H}_{2} \mathrm{O}, \mathrm{Cu} / \mathrm{CuSO}_{4}, \\
\text { microwave, } 110{ }^{\circ} \mathrm{C}, 20 \text { min }\end{array}$ & $52^{b}$ \\
& $\begin{array}{l}\text { c } \quad \mathrm{CH}_{2} \mathrm{CH}_{2} \mathrm{CH}\left(\mathrm{CH}_{3}\right)_{2} \\
\text { (iii) } t \text {-BuOH} / \mathrm{H}_{2} \mathrm{O}, \mathrm{Cu} / \mathrm{CuSO}_{4}, \\
\text { microwave, } 110{ }^{\circ} \mathrm{C}, 20 \text { min }\end{array}$ & $45^{b}$ \\
\hline
\end{tabular}

${ }^{a}$ Two step procedure showing yield of individual reactions. ${ }^{b}$ Overall yield for the one pot cycloaddition-alkylation procedure performed in a sealed microwave reactor.

40 Production of the tropones from the corresponding methyl ethers remains elusive. Nucleophilic displacement reactions employing 21a as the model system and $\mathrm{NaI}$ or thiolate anions in DMSO or TMSI in $\mathrm{CH}_{3} \mathrm{CN}$ did not afford the desired product. Starting material was recovered in all cases. Use of ${ }_{45}$ Lewis acids such as $\mathrm{BBr}_{3}$ or $\mathrm{Hg}\left(\mathrm{NO}_{3}\right)_{2}$, not unexpectedly, cleaved both ethers of 21a and afforded a complex mixture of products. Mass spectrometric analysis of the crude reaction mixtures indicated that $4(\mathrm{R}=\mathrm{H})$ was present but all attempts to isolate the compound using silica gel chromatography ${ }_{50}$ failed. 


\section{Conclusions}

The work described here represents the first attempt to incorporate structural elements of an unusual and highly complex diterpenoid, harringtonolide, into a library of simpler 5 probe molecules. The novel 5-5-7 ring system inspired by the natural product was synthesized from readily available, inexpensive starting materials. Key intermediates were easily isolated, purified and stored to facilitate production of the scaffold 20a and enumeration into libraries 21a-f and 23a-c 10 containing a fused cycloheptatriene moiety.

Although the final tropone substructure was not obtained, the resulting library is nevertheless based on a scaffold that incorporates a fused 5-7 ring substructure with appropriate substitution and stereochemistry at positions that closely 15 resemble that of the natural product.

This preliminary study suggests that use of 5methoxyindanone $\mathbf{2 4}$ as the starting material may afford a library based on the 5-5-7 scaffold 25 (Scheme 4) in which the positioning of the two oxygen functionalities more closely 20 resembles templates based on the natural product, e.g. 19. The syntheis of $\mathbf{2 5}$ will shed light on whether it is the replacement of the 6-membered ring by a 5-membered ring or the different substitution pattern between oxygen functionalities in $\mathbf{2 0}$ that confers greater stability.

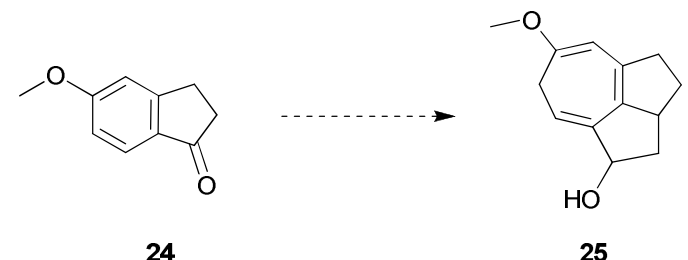

Scheme 4 Production of a second 5-5-7 series based on 5methoxyindanone

Finally, while our motivation is defined by a continuing quest to identify new privileged structures and scaffolds 30 embedded within natural products for drug discovery, ${ }^{24,25}$ screening the cycloheptatriene probe library also has potential to provide additional insights into the already rich biological activity of harringtonolide itself. In this respect, our approach complements the ongoing efforts of others ${ }^{26}$, ${ }_{35}^{27}$ to find accessible routes to the synthesis of 1 and closely related analogues such as hainanolidol for screening and drug discovery.

\section{Experimental}

\section{General}

${ }_{40}$ Starting materials and reagents used in reactions and purification were obtained from commercial suppliers and used without further purification unless otherwise stated. Silica chromatography was conducted using Merck Kieselgel 60 silica as the adsorbant. IR spectra were recorded on a Bruker 45 Tensor 27 spectrometer. Proton and carbon-13 nuclear magnetic resonance $\left({ }^{1} \mathrm{H}\right.$ NMR and ${ }^{13} \mathrm{C}$ NMR) spectra were recorded on a Varian Unity INOVA $500 \mathrm{MHz}$ spectrometer. The ${ }^{1} \mathrm{H}$ NMR chemical shifts were referenced to the residual $\mathrm{CHCl}_{3}$ peak at $7.26 \mathrm{ppm}$ in $\mathrm{CDCl}_{3}$ or $\mathrm{CH}_{3} \mathrm{COCH}_{3}$ resonance at
${ }_{50} 2.09 \mathrm{ppm}$ in acetone- $\mathrm{D}_{6}$. The ${ }^{13} \mathrm{C}$ NMR chemical shifts were referenced to the central peak of $\mathrm{CDCl}_{3}$ at $77.16 \mathrm{ppm} .{ }^{28}{ }^{1} \mathrm{H}$ NMR and ${ }^{13} \mathrm{C}$ NMR assignments were made with the aid of COSY, ROESY, HMBC and HSQC experiments. Low resolution ESI mass spectra (LRESIMS) were recorded on a ${ }_{55}$ Waters ZQ mass spectrometer. High resolution ESI mass spectra (HRESIMS) were measured on a Bruker Daltonics Apex III 4.7e Fourier transform mass spectrometer, fitted with an Apollo API source. Melting points (mp) were recorded on a Cole-Parmer hot stage and are uncorrected. Schrödinger's Macromodel 9.8 and ${ }_{60}$ Maestro 9.1 were used to minimise and superimpose the 5-5-7 and 5-6-7 scaffolds respectively. Accelrys' Pipeline Pilot Student Edition 6.1.5 was used to calculate Tanimoto similarity coefficients.

\section{Cheminformatics}

${ }_{65}$ The 5-6-7 and 5-5-7 ring scaffolds $4(\mathrm{R}=\mathrm{H})$ and 20a, respectively, were minimised using the MMFFs force-field with default settings $\left(\mathrm{H}_{2} \mathrm{O}\right.$ solvation, PRCG gradient optimization) on Macromodel (MacroModel, version 9.8, Schrödinger, LLC, New York, NY, 2010). The minimised 70 structures were overlayed by manual manipulation into the same plane followed by rigid superposition in Maestro (Maestro, version 9.1, Schrödinger, LLC, New York, NY, 2010) by defining the corresponding oxygen atom pairs.

As described by Shelat and Guy, ${ }^{17}$ the MurkoAssemblies 75 option of Pipeline Pilot's Generate Fragments component (Pipeline Pilot Student Edition, version 6.1.5, Accelrys Software Inc., San Diego, CA, 2007) was used to transform compounds $4(\mathrm{R}=\mathrm{H})$ and 20a into their respective scaffolds while retaining exocyclic double bonds and excluding $\alpha$ 80 attachment atoms. The Tanimoto similarity coefficient (Tc) was calculated from the generated scaffolds using SciTegic ${ }^{\circledR}$ path-based fingerprints with Daylight-like atom types and a 4atom maximum depth (EPFP_4). Identical results were obtained using SciTegic ${ }^{\circledR}$ Extended Connectivity fingerprints 85 (ECFP4).

\section{Ethyl 6'-methoxy-1',2',3',4'-tetrahydro-1'-naphthylacetate (9)}

Triethyl phosphonoacetate $(10.54 \mathrm{~g}, 47.0 \mathrm{mmol})$ was added dropwise over $25 \mathrm{~min}$ to a stirred suspension of sodium hydride (60\% dispersion in mineral oil, $1.88 \mathrm{~g}, 47.0 \mathrm{mmol})$ in 90 dry toluene $(30 \mathrm{~mL})$ at $0{ }^{\circ} \mathrm{C}$. The clear reaction mixture was stirred at room temperature for a further $15 \mathrm{~min}$ and then cooled to $0{ }^{\circ} \mathrm{C}$. A solution of 6-methoxy-1-tetralone $(4.0 \mathrm{~g}$, $22.7 \mathrm{mmol})$ in toluene $(45 \mathrm{~mL})$ was then added over $10 \mathrm{~min}$ after which time the reaction mixture was heated to reflux for $9514 \mathrm{~h}$. The reaction mixture was then cooled to room temperature and diluted with ethyl acetate $(50 \mathrm{~mL})$ and washed with brine $(2 \times 50 \mathrm{~mL})$. The aqueous layer was extracted with ethyl acetate $(2 \times 30 \mathrm{~mL})$ and the combined organic extracts washed with brine $(50 \mathrm{~mL})$, dried over 100 anhydrous sodium sulfate, filtered and concentrated at reduced pressure. The crude product was purified on silica (hexane:ethyl acetate, 98:2) to afford $3.59 \mathrm{~g}(64.2 \%)$ of $\mathbf{8}$ as an oil containing a mixture of of endo- and $(E, Z)$ exo-double bond isomers. The adducts were dissolved in ethanol $(35 \mathrm{~mL})$ 105 without further purification and stirred in the presence of $10 \%$ 
Pd-C (110 mg) under a hydrogen atmosphere at $50{ }^{\circ} \mathrm{C}$ for $5 \mathrm{~h}$. After this time, the reaction mixture was filtered through Celite $^{\circledR}$ and concentrated at reduced pressure. The crude product was purified on a silica column (hexane:ethyl acetate, $\left.{ }_{5} 98: 2\right)$ to afford $3.31 \mathrm{~g}(91 \%, 58.5 \%$ overall yield) of the title compound as a colourless oil with the same ${ }^{1} \mathrm{H}$ NMR spectrum and molecular ion as previously reported: ${ }^{20} \delta_{\mathrm{H}}(500 \mathrm{MHz}$, $\left.\left.\mathrm{CDCl}_{3}\right) 7.07(\mathrm{~d}, J=8.5 \mathrm{~Hz}, 1 \mathrm{H}, \mathrm{H}-8)^{\prime}\right), 6.70(\mathrm{dd}, J=2.5,8.5$ $\left.\mathrm{Hz}, 1 \mathrm{H}, \mathrm{H}-7^{\prime}\right), 6.60$ (d, $\left.J=2.5 \mathrm{~Hz}, 1 \mathrm{H}, \mathrm{H}-5^{\prime}\right), 4.17$ (q, $J=7.1$ $\left.{ }_{10} \mathrm{~Hz}, 2 \mathrm{H}, \mathrm{CO}_{2} \mathrm{CH}_{2} \mathrm{CH}_{3}\right), 3.76\left(\mathrm{~s}, 3 \mathrm{H}, \mathrm{OCH}_{3}\right), 3.29(\mathrm{~m}, 1 \mathrm{H}, \mathrm{H}-$ $\left.1^{\prime}\right), 2.75\left(\mathrm{~m}, 2 \mathrm{H}, \mathrm{CHCH}_{2} \mathrm{CO}\right), 2.66(\mathrm{dd}, J=5.0,10.0 \mathrm{~Hz}, 1 \mathrm{H}$, H-4'), 2.48 (dd, $\left.J=10.0,14.75 \mathrm{~Hz}, 1 \mathrm{H}, \mathrm{H}^{\prime}-4{ }^{\prime}\right), 1.92-1.65$ (m, $\left.4 \mathrm{H}, \mathrm{H}^{-2}, \mathrm{H}^{\prime}-2^{\prime}, \mathrm{H}^{-} 3^{\prime}, \mathrm{H}^{\prime}-3^{\prime}\right), 1.27$ (t, $J=7.2 \mathrm{~Hz}, 3 \mathrm{H}$, $\left.\mathrm{COCH}_{2} \mathrm{CH}_{3}\right) ; \quad \delta_{\mathrm{C}}\left(125 \mathrm{MHz}, \mathrm{CDCl}_{3}\right) 173.02(\mathrm{CO}), 157.83$ 15 (C6'), 138.48 (C4'a), 131.69 (C8'a), 129.36 (C8'), 113.83 (C5'), 112.31 (C7'), $60.46\left(\mathrm{CH}_{2} \mathrm{CH}_{3}\right), 55.34\left(\mathrm{OCH}_{3}\right), 42.34$ $\left(\mathrm{CH}_{2} \mathrm{CO}\right), 34.09\left(\mathrm{C}^{\prime}\right), 30.04\left(\mathrm{C}^{\prime}\right), 28.56\left(\mathrm{C}^{\prime}\right), 19.72\left(\mathrm{C}^{\prime}\right)$, $14.42\left(\mathrm{CH}_{2} \mathrm{CH}_{3}\right) ;(+)$ LRESIMS $m / z 271[\mathrm{M}+\mathrm{Na}]^{+}$.

\section{6'-Methoxy-1',2',3',4'-tetrahydro-1'-naphthylacetic acid (10)}

20 The ester 9 (2.73 g, $11.0 \mathrm{mmol})$ was dissolved in $1 \mathrm{M} \mathrm{NaOH}$ $(90 \%$ methanol in water, $60 \mathrm{~mL}$ ) and stirred at room temperature for $3 \mathrm{~h}$. The reaction mixture was concentrated, dissolved in water $(50 \mathrm{~mL})$, acidified with $5 \mathrm{M} \mathrm{HCl}(12 \mathrm{~mL})$ and extracted with ethyl acetate $(3 \times 40 \mathrm{~mL})$. The organic 25 extract was washed with brine $(2 \times 40 \mathrm{~mL})$, dried over anhydrous sodium sulfate, filtered and concentrated at reduced pressure to afford the crude product which was purified on a silica column (hexane:ethyl acetate, $85: 15$ ) to yield the title compound ${ }^{29}$ as a white solid $(2.37 \mathrm{~g}, 97.8 \%)$ : $30 \mathrm{mp} 80-82{ }^{\circ} \mathrm{C} ; \delta_{\mathrm{H}}\left(500 \mathrm{MHz}, \mathrm{CDCl}_{3}\right) 7.10(\mathrm{~d}, J=8.5 \mathrm{~Hz}, 1 \mathrm{H}$, H-8'), $6.72\left(\mathrm{dd}, J=2.5,7.7 \mathrm{~Hz}, 1 \mathrm{H}, \mathrm{H}^{\prime} 7^{\prime}\right), 6.62(\mathrm{~d}, J=2.0 \mathrm{~Hz}$, $1 \mathrm{H}, \mathrm{H}-5$ '), 3.77 (s, 3H, OCH $\left.H_{3}\right), 3.32\left(\mathrm{~m}, 1 \mathrm{H}, \mathrm{H}-1^{\prime}\right), 2.81-2.70$ (m, 3H, $\mathrm{CH}_{2} \mathrm{CO}, \mathrm{H}-4$ '), $2.56\left(\mathrm{dd}, J=10.0,15.5 \mathrm{~Hz}, 1 \mathrm{H}, \mathrm{H}^{\prime}-\right.$ 4') 1.98-1.92 (m, 1H, H-2'), 1.87-1.71 (m, 3H, H'-2', H-3', $\left.{ }_{35} \mathrm{H}^{\prime}-3^{\prime}\right) ; \delta_{\mathrm{C}}\left(125 \mathrm{MHz}, \mathrm{CDCl}_{3}\right) 178.82(\mathrm{CO}), 157.92$ (C6'), 138.53 (C4'a), 131.30 (C8'a), 129.30 (C8'), 113.91 (C5'), $112.43\left(\mathrm{C}^{\prime}\right), 55.35\left(\mathrm{OCH}_{3}\right), 41.93\left(\mathrm{CH}_{2} \mathrm{CO}\right), 33.89\left(\mathrm{C} 1^{\prime}\right)$, 29.99 (C4'), 28.43 (C2'), 19.66 (C3'); (+)-LRESIMS m/z 243 $[\mathrm{M}+\mathrm{Na}]^{+}$; (+)-HRESIMS $m / z \quad 243.0992, \mathrm{C}_{13} \mathrm{H}_{16} \mathrm{O}_{3} \quad[\mathrm{M}+\mathrm{Na}]^{+}$ 40 requires 243.0992.

\section{3-(6'-Methoxy-1',2',3',4'-tetrahydro-1'-naphthyl)-1-diazo- propane-2-one (11)}

The title compound was prepared according to the method reported by Mander et. al. ${ }^{15}$ as a yellow solid: mp $82-84{ }^{\circ} \mathrm{C}$ 45 (lit. $\left.{ }^{15} 84-86{ }^{\circ} \mathrm{C}\right) ; \delta_{\mathrm{H}}\left(500 \mathrm{MHz}, \mathrm{CDCl}_{3}\right) 7.05(\mathrm{~d}, J=9.0 \mathrm{~Hz}$, $\left.1 \mathrm{H}, \mathrm{H}-8^{\prime}\right), 6.69$ (dd, $\left.J=2.5,8.5 \mathrm{~Hz}, 1 \mathrm{H}, \mathrm{H}-7^{\prime}\right), 6.60(\mathrm{~d}, J=$ $\left.2.0 \mathrm{~Hz}, 1 \mathrm{H}, \mathrm{H}-5^{\prime}\right), 5.20$ (br s, $\left.1 \mathrm{H}, \mathrm{CH}=\mathrm{N}\right), 3.76\left(\mathrm{~s}, 3 \mathrm{H}, \mathrm{OCH}_{3}\right)$, $3.36(\mathrm{~m}, 1 \mathrm{H}, \mathrm{H}-1 \mathrm{\prime}), 2.78-2.51(\mathrm{~m}, 4 \mathrm{H}), 1.93-1.87(\mathrm{~m}, 1 \mathrm{H})$, $1.82-1.64(\mathrm{~m}, 3 \mathrm{H}) ; \delta_{\mathrm{C}}\left(125 \mathrm{MHz}, \mathrm{CDCl}_{3}\right) 194.25(\mathrm{CO}), 157.84$ 50 (C6'), 138.48 (C4'a), 131.76 (C8'a), 129.41 (C8'), 113.87 (C5'), $112.33\left(\mathrm{C}^{\prime}\right), 55.33\left(\mathrm{OCH}_{3}\right), 55.25\left(\mathrm{CH}=\mathrm{N}_{2}\right), 48.69$ (C1'), $33.80\left(\mathrm{CH}_{2} \mathrm{CO}\right), 30.01$ (C4'), $28.53\left(\mathrm{C}^{\prime}\right), 19.76\left(\mathrm{C}^{\prime}\right)$; (+)-LRESIMS $m / z \quad 267 \quad[\mathrm{M}+\mathrm{Na}]^{+} ; \quad(+)$-HRESIMS $\mathrm{m} / \mathrm{z}$ 267.1099, $\mathrm{C}_{14} \mathrm{H}_{16} \mathrm{~N}_{2} \mathrm{O}_{2}[\mathrm{M}+\mathrm{Na}]^{+}$requires 267.1104.

${ }_{55}$ 7-Methoxy-1,2,2a,3,4,5-hexahydro-(8H)-benz[cd]-azulen-1one (12)
The title compound was prepared according to the method reported by Mander et. al. ${ }^{15}$ and obtained as an unstable white solid that gradually turned grey: $\delta_{\mathrm{H}}\left(500 \mathrm{MHz}, \mathrm{CDCl}_{3}\right) 5.99$ 60 (dd, $J=6.0,8.0 \mathrm{~Hz}, 1 \mathrm{H}, \mathrm{H}-9), 5.28$ (s, 1H, H-6), 3.60 (s, 3H, $\left.\mathrm{OCH}_{3}\right), 3.19(\mathrm{~m}, 1 \mathrm{H}, \mathrm{H}-8), 2.95-2.80(\mathrm{~m}, 1 \mathrm{H}, \mathrm{H}-2 \mathrm{a}), 2.73$ (dd, $J=8.0,18.2 \mathrm{~Hz}, 1 \mathrm{H}, \mathrm{H}-2), 2.51-2.48$ (m, 2H, H-5, H'-5), 2.22-2.17 (m, 2H, H'-8, H-3), 2.05 (dd, $J=9.0,15.7 \mathrm{~Hz}, 1 \mathrm{H}$, $\left.\mathrm{H}^{\prime}-2\right)$, 2.03-1.97 (m, 1H, H-4), 1.76-1.67 (m, 1H, H'-4), 1.28${ }_{65} 1.20\left(\mathrm{~m}, 1 \mathrm{H}, \mathrm{H}^{\prime}-3\right)$; $\delta_{\mathrm{C}}\left(125 \mathrm{MHz}, \mathrm{CDCl}_{3}\right) 206.00(\mathrm{C} 1)$, 146.99 (C7), 139.09, 136.13, 134.57 (C5a, C9a, C9b), 115.44 (C9), 101.36 (C6), $56.29\left(\mathrm{OCH}_{3}\right), 46.05(\mathrm{C} 2 \mathrm{a}), 36.05,32.76$ (C2, C8), 31.00, 29.86 (C3, C5), 22.68 (C4); (+)-LRESIMS $\mathrm{m} / \mathrm{z}, 217[\mathrm{M}+\mathrm{H}]^{+}$.

\section{7-Methoxy-1,2,2a,3,4,5-hexahydro-(8H)-benz[cd]-azulen-1-ol} (19)

The title compound was prepared according to the method reported by Mander et. al. ${ }^{15}$ and obtained as an unstable white solid that gradually turned grey: $\delta_{\mathrm{H}}\left(500 \mathrm{MHz}, \mathrm{CDCl}_{3}\right) 5.35(\mathrm{t}$, $\left.{ }_{75} J=6.5 \mathrm{~Hz}, \mathrm{H}-9\right), 5.08$ (s, 1H, H-6), $4.65(\mathrm{~m}, 1 \mathrm{H}, \mathrm{H}-1), 3.57$ (s, 3H, OCH $H_{3}, 2.92(\mathrm{~m}, 1 \mathrm{H}, \mathrm{H}-2), 2.52(\mathrm{~m}, 2 \mathrm{H}, \mathrm{H}-2 \mathrm{a}, \mathrm{H}-5)$, $2.43\left(\mathrm{dd}, J=5.0,14.0 \mathrm{~Hz}, 1 \mathrm{H}, \mathrm{H}^{\prime}-2\right), 2.34$ (m, 2H, H-8, H-8'), $2.05(\mathrm{~m}, 1 \mathrm{H}, \mathrm{H}-3), 1.87$ (dt, $J=3.5,13.0 \mathrm{~Hz}, 1 \mathrm{H}, \mathrm{H}-4), 1.62-$ $1.46\left(\mathrm{~m}, 1 \mathrm{H}, \mathrm{H}-4^{\prime}\right), 1.22-1.06\left(\mathrm{~m}, 2 \mathrm{H}, \mathrm{H}-5^{\prime}, \mathrm{H}-3^{\prime}\right) ; \delta_{\mathrm{C}}(125$ $\left.{ }_{80} \mathrm{MHz}, \mathrm{CDCl}_{3}\right)$ 149.01 (C7), 146.32 (C9a), 134.97, 132.18 (C5a, C9b), 110.70 (C9), 99.83 (C6), 73.29 (C1), 55.78 $\left(\mathrm{OCH}_{3}\right), 44.60(\mathrm{C} 5), 38.56(\mathrm{C} 2 \mathrm{a}), 32.50(\mathrm{C} 2), 31.60(\mathrm{C} 8)$, 29.90 (C3), 22.85 (C4); (+)-LRESIMS m/z $219[\mathrm{M}+\mathrm{H}]^{+}, 231$ $[\mathrm{M}+\mathrm{Na}]^{+}$.

\section{${ }_{85}$ Ethyl 2-(6'-methoxy-2',3'-dihydro-1' $H$-inden-1'-yl)acetate (14)}

Triethyl phosphonoacetate $(4.15 \mathrm{~g}, 18.5 \mathrm{mmol})$ was added dropwise over $20 \mathrm{~min}$ to a stirred suspension of sodium hydride ( $60 \%$ dispersion in mineral oil, $0.74 \mathrm{~g}, 18.5 \mathrm{mmol}$ ) in 90 dry $\mathrm{THF}(40 \mathrm{~mL})$ at $0{ }^{\circ} \mathrm{C}$ under argon. Upon complete addition, the clear reaction mixture was stirred at room temperature for $30 \mathrm{~min}$ and cooled to $0{ }^{\circ} \mathrm{C}$. A solution of 6methoxy-1-indanone $(2.5 \mathrm{~g}, 15.4 \mathrm{mmol})$ in THF $(10 \mathrm{~mL})$ was then added over of $5 \mathrm{~min}$ and the resulting mixture stirred at 95 room temperature for $1 \mathrm{~h}$ and heated to reflux for a further 15 $\mathrm{h}$. The reaction mixture was cooled to room temperature and diluted with ethyl acetate $(50 \mathrm{~mL})$ and washed with brine $(2 \times$ $40 \mathrm{~mL}$ ). The aqueous layer was extracted with ethyl acetate (2 $\times 30 \mathrm{~mL})$ and the combined organic extracts washed with 100 brine $(40 \mathrm{~mL})$, dried over anhydrous sodium sulfate, filtered and concentrated at reduced pressure. The crude product was purified on silica (hexane:ethyl acetate, 98:2) to yield $2.59 \mathrm{~g}$ $(72.3 \%)$ of $\mathbf{1 3}$ as a colourless oil containing a mixture of of endo- and $(E, Z)$ exo-double bond isomers. The adducts were 105 dissolved in ethanol $(45 \mathrm{~mL})$ without further purification and stirred in the presence of $10 \% \mathrm{Pd}-\mathrm{C}(200 \mathrm{mg})$ under a hydrogen atmosphere at $50{ }^{\circ} \mathrm{C}$ for $8 \mathrm{~h}$. After this time, the reaction mixture was filtered through Celite ${ }^{\circledR}$ and concentrated at reduced pressure. The crude product was purified on a 110 silica column (hexane:ethyl acetate, 98:2) to afford $2.56 \mathrm{~g}$ ( $98 \%, 70.9 \%$ overall yield) of the title compound as colourless oil with the same ${ }^{1} \mathrm{H}$ NMR spectrum as previously reported ${ }^{21}$ : $\delta_{\mathrm{H}}\left(500 \mathrm{MHz}, \mathrm{CDCl}_{3}\right) 7.11(\mathrm{~d}, J=8.0 \mathrm{~Hz}, 1 \mathrm{H}, \mathrm{H}-4$ '), 6.74- 
$6.71\left(\mathrm{~m}, 2 \mathrm{H}, \mathrm{H}-7, \mathrm{H}-5{ }^{\prime}\right), 4.18(\mathrm{q}, J=7.0 \mathrm{~Hz}, 2 \mathrm{H}$, $\mathrm{CO}_{2} \mathrm{CH}_{2} \mathrm{CH}_{3}$ ), 3.77 (s, $3 \mathrm{H}, \mathrm{OCH}_{3}$ ), 3.55 (pent, $J=7.3 \mathrm{~Hz}, 1 \mathrm{H}$, H-1'), 2.89-2.72 (m, 3H, $\mathrm{CHCH}_{2} \mathrm{CO}, \mathrm{H}-3$ '), 2.45-2.35 (m, 2H, $\mathrm{H}^{\prime}-3$ ', H-2'), 1.76 (m, 1H, H'-2'), 1.28 (t, $J=7.0 \mathrm{~Hz}, 3 \mathrm{H}$, $\left.\mathrm{COCH}_{2} \mathrm{CH}_{3}\right)$; (+)-LRESIMS $\mathrm{m} / \mathrm{z}, 257[\mathrm{M}+\mathrm{Na}]^{+}$.

\section{2-(6'-Methoxy-2',3'-dihydro-1' $H$-inden-1'-yl)acetic acid (15)}

The ester 14 (2.55 g, $10.89 \mathrm{mmol})$ was dissolved in $1 \mathrm{M} \mathrm{NaOH}$ (90\% methanol in water, $60 \mathrm{~mL}$ ) and stirred at room temperature for $3 \mathrm{~h}$. The reaction mixture was concentrated, 10 dissolved in water $(50 \mathrm{~mL})$, acidified with $5 \mathrm{M} \mathrm{HCl}(13 \mathrm{~mL})$ and extracted with ethyl acetate $(3 \times 40 \mathrm{~mL})$. The ethyl acetate extract was washed with brine $(2 \times 40 \mathrm{~mL})$, dried over anhydrous sodium sulfate, filtered and concentrated at reduced pressure to afford the crude product which was 15 purified on silica gel (hexane:ethyl acetate, 85:15) to yield the title compound as a white solid $(2.37 \mathrm{~g}, 97.6 \%)$ : $\mathrm{mp}$ 65-68 ${ }^{\circ} \mathrm{C}$; $v_{\max }\left(\mathrm{cm}^{-1}\right) 3300-2500(\mathrm{COOH}), 3005(\mathrm{ArH}), 2835(\mathrm{CH}), 1710$ $(\mathrm{C}=\mathrm{O}), 1240\left(\mathrm{ArOCH}_{3}\right) ; \delta_{\mathrm{H}}\left(500 \mathrm{MHz}, \mathrm{CDCl}_{3}\right) 7.13(\mathrm{~d}, J=$ $\left.8.0 \mathrm{~Hz}, 1 \mathrm{H}, \mathrm{H}-4^{\prime}\right), 6.77$ (s, 1H, H-7'), 6.74 (d, $J=8.0 \mathrm{~Hz}, \mathrm{H}-$ $\left.{ }_{20} 5^{\prime}\right), 3.79\left(\mathrm{~s}, 3 \mathrm{H}, \mathrm{OCH}_{3}\right), 3.57\left(5, J=7.2 \mathrm{~Hz}, 1 \mathrm{H}, \mathrm{H}-1^{\prime}\right), 2.91-$ $2.81\left(\mathrm{~m}, 3 \mathrm{H}, \mathrm{COCH}_{2}, \mathrm{H}-3{ }^{\prime}\right), 2.52-2.40\left(\mathrm{~m}, 2 \mathrm{H}, \mathrm{H}^{\prime}-3{ }^{\prime}, \mathrm{H}-2^{\prime}\right)$, 1.79 (sext, $\left.J=7.2 \mathrm{~Hz}, 1 \mathrm{H}, \mathrm{H}^{\prime}-2 '\right) ; \delta_{\mathrm{C}}\left(125 \mathrm{MHz}, \mathrm{CDCl}_{3}\right)$ 179.06 (CO), 159.15 (C6'), 147.24 (C7'a), 136.13 (C3'a), 125.41 (C4'), 112.97 (C5'), $109.58\left(\mathrm{C}^{\prime}\right), 55.82\left(\mathrm{OCH}_{3}\right), 41.63$ ${ }_{25}\left(\mathrm{CH}_{2} \mathrm{CO}\right), 39.90\left(\mathrm{C}^{\prime}\right), 33.25\left(\mathrm{C}^{\prime}\right), 30.64\left(\mathrm{C}^{\prime}\right)$; (+)-LRESIMS $\mathrm{m} / \mathrm{z} 229 \quad[\mathrm{M}+\mathrm{Na}]^{+} ;(+)$-HRESIMS $\mathrm{m} / \mathrm{z} \quad 229.0825, \mathrm{C}_{12} \mathrm{H}_{14} \mathrm{O}_{3}$ $[\mathrm{M}+\mathrm{Na}]^{+}$requires 229.0835 .

\section{1-Diazo-3-(6'-methoxy-2',3'-dihydro-1' $H$-inden-1'-yl)propan-} 2-one (16)

30 A solution of the acid $13(1.29 \mathrm{~g}, 6.26 \mathrm{mmol})$ in DCM (20 $\mathrm{mL})$ was carefully added to a mixture of oxalyl chloride (1.6 $\mathrm{g}, 12.53 \mathrm{mmol})$ and DMF $(0.2 \mathrm{~mL})$ at $-5{ }^{\circ} \mathrm{C}$ dropwise over 10 min all the while ensuring the temperature did not rise above $0{ }^{\circ} \mathrm{C}$. The reaction mixture was then stirred at $0-5{ }^{\circ} \mathrm{C}$ for $1 \mathrm{~h}$ 35 and ambient temperature for an additional $1 \mathrm{~h}$ and the mixture was concentrated at reduced pressure to afford a thick yellow oil. The residue was taken up in toluene $(10 \mathrm{~mL})$ and added dropwise to a solution of freshly prepared diazomethane in diethyl ether $(25 \mathrm{~mL})$ at $0{ }^{\circ} \mathrm{C}$ (CARE). The reaction mixture 40 stirred at $0-5{ }^{\circ} \mathrm{C}$ for $2 \mathrm{~h}$ and then overnight at $25{ }^{\circ} \mathrm{C}$. Excess diazomethane and diethyl ether was removed by bubbling nitrogen gas into the reaction mixture. The crude yellow product was purified on silica gel (hexane:ethyl acetate, 95:5 $\rightarrow 90: 10)$ to yield $1.22 \mathrm{~g}(84.5 \%)$ of the title compound as a 45 bright yellow solid: $\mathrm{mp} 45-46{ }^{\circ} \mathrm{C} ; v_{\max }\left(\mathrm{cm}^{-1}\right) 3090(\mathrm{ArH})$, $2940(\mathrm{CH}), 2102\left(\mathrm{CHN}_{2}\right), 1640(\mathrm{C}=\mathrm{O}), 1490\left(\mathrm{CH}_{2}\right), 1240$ $\left(\mathrm{ArOCH}_{3}\right) ; \delta_{\mathrm{H}}\left(500 \mathrm{MHz}, \mathrm{CDCl}_{3}\right) \delta 7.11(\mathrm{~d}, J=7.5 \mathrm{~Hz}, 1 \mathrm{H}$, H-4'), 6.72 (m, 2H, H-7', H-5'), 5.24 (br s, $1 \mathrm{H}, \mathrm{CH}=\mathrm{N}_{2}$ ), 3.78 (s, $3 \mathrm{H}, \mathrm{OCH}_{3}$ ), 3.61 (pent, $1 \mathrm{H}, J=7.1 \mathrm{~Hz}, \mathrm{H}-1^{\prime}$ ), 2.88-2.74 $50\left(\mathrm{~m}, 3 \mathrm{H}, \mathrm{COCH}_{2}, \mathrm{H}^{-} 3^{\prime}\right), 2.44-2.34$ (m, 2H, H'-3', H-2'), 1.74 (sext, $\left.J=7.1 \mathrm{~Hz}, 1 \mathrm{H}, \mathrm{H}^{\prime}-2^{\prime}\right) ; \delta_{\mathrm{C}}\left(125 \mathrm{MHz}, \mathrm{CDCl}_{3}\right) 193.91$ (CO), 158.90 (C6'), 147.52 (C7'a), 135.89 (C3'a), 125.16 (C4'), 112.64 (C5'), 109.40 (C7'), $55.60\left(\mathrm{OCH}_{3}\right), 55.04$ $\left(\mathrm{CHN}_{2}\right), 46.49\left(\mathrm{CH}_{2} \mathrm{CO}\right), 41.73\left(\mathrm{C}^{\prime}\right), 32.94\left(\mathrm{C}^{\prime}\right), 30.47$ ${ }_{55}$ (C2'); (+)-LRESIMS m/z $253[\mathrm{M}+\mathrm{Na}]^{+}$; (+)-HRESIMS $\mathrm{m} / \mathrm{z}$ 253.0943, $\mathrm{C}_{13} \mathrm{H}_{14} \mathrm{~N}_{2} \mathrm{O}_{2}[\mathrm{M}+\mathrm{Na}]^{+}$requires 253.0947.
7-Methoxy-2,2a,3,4-tetrahydro-(8H)-cyclopenta[cd]azulen-1one (17)

A solution of the diazoketone $\mathbf{1 6}(252 \mathrm{mg}, 1.1 \mathrm{mmol})$ in dry ${ }_{60}$ DCE $(25 \mathrm{~mL})$ was added slowly $(25 \mu \mathrm{L} / \mathrm{min})$ via a syringe pump fitted with fine Teflon ${ }^{\circledR}$ tubing into a solution of copper (II) ethylacetoacetate $(22 \mathrm{mg}, 6 \mathrm{~mol} \%)$ in dry DCE $(25 \mathrm{~mL})$ at mild reflux under an inert argon atmosphere. The reaction mixture was heated to reflux for $15 \mathrm{~min}$ and cooled to room ${ }_{65}$ temperature. DBU $(0.25 \mathrm{~mL})$ was added dropwise under argon and the mixture stirred for a further $10 \mathrm{~min}$. After this time, the reaction mixture was diluted with DCM $(50 \mathrm{~mL})$ and washed with $1 \mathrm{M} \mathrm{HCl}(40 \mathrm{~mL})$ followed by brine $(2 \times 50 \mathrm{~mL})$. The organic layer was decanted and dried over anhydrous 70 sodium sulfate. The solvent was removed at reduced pressure to afford the reddish brown crude product which was purified on silica gel (hexane:ethyl acetate, 98:2) to afford $165 \mathrm{mg}$ of the title compound as a white solid $(74.5 \%)$ : $\mathrm{mp} 82-84{ }^{\circ} \mathrm{C}$; $v_{\max }\left(\mathrm{cm}^{-1}\right) 3010(\mathrm{ArH}), 1710(\mathrm{C}=\mathrm{O}), 1485\left(\mathrm{CH}_{2}\right), 1250$ $75\left(\mathrm{OCH}_{3}\right) ; \delta_{\mathrm{H}}\left(500 \mathrm{MHz}, \mathrm{CDCl}_{3}\right) 7.10(\mathrm{~d}, J=8.0 \mathrm{~Hz}, 1 \mathrm{H}, \mathrm{H}-5)$, $6.69(\mathrm{~d}, J=8.0 \mathrm{~Hz}, 1 \mathrm{H}, \mathrm{H}-6), 3.81\left(\mathrm{~s}, 3 \mathrm{H}, \mathrm{OCH}_{3}\right), 3.60(\mathrm{~d}, J=$ $22.0 \mathrm{~Hz}, 1 \mathrm{H}, \mathrm{H}-2), 3.36-3.26$ (m, 2H, H-2a, H'-2), 2.97-2.83 (m, 3H, H-8, H'-8, H-4), 2.49 (pent, $J=6.3 \mathrm{~Hz}, 1 \mathrm{H}, \mathrm{H}-3$ ), $2.21\left(\mathrm{~m}, 1 \mathrm{H}, \mathrm{H}^{\prime}-4\right), 1.72\left(\mathrm{~m}, 1 \mathrm{H}, \mathrm{H}^{\prime}-3\right) ; \delta_{\mathrm{C}}\left(125 \mathrm{MHz}, \mathrm{CDCl}_{3}\right)$ ${ }_{80} 210.91$ (C1), 155.58 (C7), 144.63 (C8b), 134.42 (C4a), 123.06 (C8a), 119.08 (C5), 109.16 (C6), $55.97\left(\mathrm{OCH}_{3}\right), 47.00$ (C4), 40.44 (2a), 37.27 (C2), 35.89 (C3), 31.81 (C8); (+)-LRESIMS $m / z \quad 225 \quad[\mathrm{M}+\mathrm{Na}]^{+} ;(+)$-HRESIMS $\mathrm{m} / z \quad 225.0888, \mathrm{C}_{13} \mathrm{H}_{14} \mathrm{O}_{2}$ $[\mathrm{M}+\mathrm{Na}]^{+}$requires 225.0886 .

\section{${ }_{85}$ 7-Methoxy-1,2,2a,3,4,8-hexahydrocyclopenta[cd]azulen-1-ol} (20)

To a stirred and cooled $\left(0{ }^{\circ} \mathrm{C}\right)$ solution of the cycloheptatriene $17(140 \mathrm{mg}, 0.69 \mathrm{mmol})$ in dry methanol $(15 \mathrm{~mL})$ was added sodium borohydride $(52 \mathrm{mg}, 1.37 \mathrm{mmol})$. The resulting 90 mixture was stirred for $30 \mathrm{~min}$ at $0-5{ }^{\circ} \mathrm{C} .0 .1 \mathrm{M} \mathrm{HCl}$ in brine $(25 \mathrm{~mL})$ was slowly added to the reaction mixture until evolution of hydrogen gas had ceased at which time a voluminous white suspension was observed. The product was extracted with ethyl acetate $(4 \times 20 \mathrm{~mL})$ and the organic 95 extract washed with brine $(2 \times 25 \mathrm{~mL})$. The organic layer was dried over anhydrous sodium sulfate, filtered and evaporated at reduced pressure to obtain the crude product (a 95:5 mixtutre of syn and anti isomers 20a and 20b respectively). The crude products were washed with hexane to obtain the 100 pure cis adduct $(96 \mathrm{mg}$ ). After concentrating the hexane washes at reduced pressure, the two isomers were separated on a silica gel column (hexane:ethyl acetate, $92: 8 \rightarrow 90: 10$ ) to obtain a further $35 \mathrm{mg}$ of 20a as a white solid (131 mg overall, $92.7 \%$ ) and $6 \mathrm{mg}(4.2 \%)$ of $\mathbf{2 0 b}$ as a white solid.

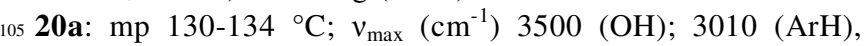
$2935(\mathrm{CH}), 1485\left(\mathrm{CH}_{2}\right), 1245\left(\mathrm{OCH}_{3}\right), 1110(\mathrm{C}-\mathrm{OH}) ; \delta_{\mathrm{H}}(500$ $\left.\mathrm{MHz}, \mathrm{CDCl}_{3}\right) 7.01(\mathrm{~d}, J=8.0 \mathrm{~Hz}, 1 \mathrm{H}, \mathrm{H}-5), 6.10$ (d, $J=8.0$ $\mathrm{Hz}, 1 \mathrm{H}, \mathrm{H}-6), 4.19$ (m, 1H, H-1), 3.80 (s, 3H, OCH $\mathrm{O}_{3}, 3.22$ (dd, $J=6.5,17.0 \mathrm{~Hz}, 1 \mathrm{H}, \mathrm{H}-2), 2.99$ (hept, $J=5.7 \mathrm{~Hz}, 1 \mathrm{H}, \mathrm{H}-$ 110 2a), 2.88-2.81 (m, $1 \mathrm{H}, \mathrm{H}-4), 2.73(\mathrm{dd}, J=7.5,14.7 \mathrm{~Hz}, 1 \mathrm{H}$, $\left.\mathrm{H}^{\prime}-4\right), 2.39$ (dd, $\left.J=10.0,17.0 \mathrm{~Hz}, \mathrm{H}^{\prime}-2\right), 2.33-2.28$ (m, 2H, H-8, H-3), 1.66-1.60 (m, 1H, H'-3), 1.37 (q, $J=11.6 \mathrm{~Hz}, 1 \mathrm{H}$, $\left.\mathrm{H}^{\prime}-8\right) ; \delta_{\mathrm{C}}\left(125 \mathrm{MHz}, \mathrm{CDCl}_{3}\right) 155.79(\mathrm{C} 7), 145.22$ (C8b), 
134.59 (C4a), 122.02 (C5), 120.71 (C8a), 108.18 (C6), 69.74 (C1), $55.69\left(\mathrm{OCH}_{3}\right), 41.75(\mathrm{C} 2 \mathrm{a}), 38.87(\mathrm{C} 8), 35.31$ (C3), 32.66 (C2), 31.71 (C4); (+)-LRESIMS m/z 227 [M+Na] ${ }^{+}$; (+)HRESIMS $m / z \quad 227.1052, \quad \mathrm{C}_{13} \mathrm{H}_{16} \mathrm{O}_{2} \quad[\mathrm{M}+\mathrm{Na}]^{+}$requires 5227.1043 .

20b: $v_{\max }\left(\mathrm{cm}^{-1}\right) 3500(\mathrm{OH}) ; 3010(\mathrm{ArH}), 2920(\mathrm{CH}), 1485$ $\left(\mathrm{CH}_{2}\right), 1245\left(\mathrm{OCH}_{3}\right), 1090(\mathrm{C}-\mathrm{OH}) ; \delta_{\mathrm{H}}\left(500 \mathrm{MHz}, \mathrm{CDCl}_{3}\right)$ 7.04 (d, $J=8.0 \mathrm{~Hz}, 1 \mathrm{H}, \mathrm{H}-5), 6.62$ (d, $J=8.0 \mathrm{~Hz}, 1 \mathrm{H}, \mathrm{H}-6)$, 4.52 (br s, $1 \mathrm{H}, \mathrm{H}-1), 3.80$ (s, $\left.3 \mathrm{H}, \mathrm{OCH}_{3}\right), 3.20$ (hept, $J=5.8$ $\left.{ }_{10} \mathrm{~Hz}, 1 \mathrm{H}, \mathrm{H}-2 \mathrm{a}\right), 2.89-2.81$ (m, 3H, H-8, H-4, H'-4), 2.77- 2.71 $\left(\mathrm{m}, 1 \mathrm{H}, \mathrm{H}^{\prime}-8\right), 2.34(\mathrm{~m}, 1 \mathrm{H}, \mathrm{H}-2), 2.28(\mathrm{~m}, 1 \mathrm{H}, \mathrm{H}-3), 1.62$ $\left(\mathrm{m}, 1 \mathrm{H}, \mathrm{H}^{\prime}-2\right), 1.33\left(\mathrm{~m}, 1 \mathrm{H}, \mathrm{H}^{\prime}-3\right) ; \delta_{\mathrm{C}}\left(125 \mathrm{MHz}, \mathrm{CDCl}_{3}\right)$ 156.39 (C7), 145.50 (C8b), 135.23 (C4a), 121.97 (C5), 119.98 (C8a), 108.18 (C6), $66.67(\mathrm{C} 1), 55.84\left(\mathrm{OCH}_{3}\right), 35.77(\mathrm{C} 2)$, 1535.67 (C3), 35.34 (C2a), 31.48, 31.47 (C4, C8); (+)LRESIMS m/z $227[\mathrm{M}+\mathrm{Na}]^{+}$; (+)-HRESIMS m/z 227.1045, $\mathrm{C}_{13} \mathrm{H}_{16} \mathrm{O}_{2}[\mathrm{M}+\mathrm{Na}]^{+}$requires 227.1043.

\section{General procedure for the synthesis of compounds 21a-c}

Alcohol 20a (24 mg, $0.12 \mathrm{mmol})$ in dry THF $(0.6 \mathrm{~mL})$ was 20 slowly added to a stirred and cooled suspension of sodium hydride $(60 \%$ dispersion in mineral oil, $14 \mathrm{mg}, 0.35 \mathrm{mmol})$ in dry THF $(1.0 \mathrm{~mL})$. Following complete addition, the reaction mixture was stirred at ambient temperature for $1 \mathrm{~h}$ under argon. The appropriate benzyl bromide $(0.176 \mathrm{mmol})$ was 25 then added and the mixture stirred for an additional $40 \mathrm{~h}$ under argon. The reaction mixture was quenched with brine ( 3 $\mathrm{mL})$ and extracted with ethyl acetate $(4 \times 2 \mathrm{~mL})$. The organic extract was washed with brine $(3 \mathrm{~mL})$, dried over anhydrous sodium sulfate, filtered and concentrated at reduced pressure. 30 The crude oil was purified on silica gel (hexane:ethyl acetate, 98:2) to obtain the desired compounds in yields ranging from $72-89 \%$.

\section{1-(Benzyloxy)-7-methoxy-1,2,2a,3,4,8- hexahydrocyclopenta[cd]azulene (21a)}

${ }_{35}$ Colourless oil; $24.9 \mathrm{mg}$ (72.0\%); $v_{\max }\left(\mathrm{cm}^{-1}\right) 3010$ (ArH), $2835\left(\mathrm{CH}_{2}\right), 1485\left(\mathrm{CH}_{2}\right), 1245\left(\mathrm{OCH}_{3}\right) ; \delta_{\mathrm{H}}\left(500 \mathrm{MHz}, \mathrm{CDCl}_{3}\right)$ $7.41(\mathrm{~d}, J=7.5 \mathrm{~Hz}, 2 \mathrm{H}, \mathrm{PhH}), 7.35(\mathrm{t}, J=7.5 \mathrm{~Hz}, 2 \mathrm{H}, \mathrm{PhH})$, $7.29(\mathrm{~d}, J=7.0 \mathrm{~Hz}, 1 \mathrm{H}, \mathrm{PhH}), 7.01(\mathrm{~d}, J=8.0 \mathrm{~Hz}, 1 \mathrm{H}, \mathrm{H}-5)$, $6.61(\mathrm{~d}, J=8.0 \mathrm{~Hz}, 1 \mathrm{H}, \mathrm{H}-6), 4.70(\mathrm{q}, J=12.3 \mathrm{~Hz}, 2 \mathrm{H}$, $\left.{ }_{40} \mathrm{OCH}_{2}\right), 3.92(\mathrm{~m}, 1 \mathrm{H}, \mathrm{H}-1) 3.81\left(\mathrm{~s}, 3 \mathrm{H}, \mathrm{OCH}_{3}\right), 3.29(\mathrm{dd}, J=$ 6.5, 8.5 Hz, 1H, H-2), 2.93 (m, 1H, H-2a), 2.84 (m, 1H, H-8), $2.72\left(\mathrm{dd}, J=8.0,15.0 \mathrm{~Hz}, \mathrm{H}^{\prime}-8\right), 2.51(\mathrm{dd}, J=9.5 \mathrm{~Hz}, 16.7$ $\left.\mathrm{Hz}, 1 \mathrm{H}, \mathrm{H}^{\prime}-2\right), 2.45$ (dt, $\left.J=3.7,11.5 \mathrm{~Hz}, 1 \mathrm{H}, \mathrm{H}-4\right), 2.30$ (pent, $\left.J=6.0 \mathrm{~Hz}, 1 \mathrm{H}, \mathrm{H}^{\prime}-4\right), 1.62(\mathrm{~m}, 1 \mathrm{H}, \mathrm{H}-3), 1.38(\mathrm{q}, J=$ $\left.4511.6 \mathrm{~Hz}, 1 \mathrm{H}, \mathrm{H}^{\prime}-3\right) ; \delta_{\mathrm{C}}\left(125 \mathrm{MHz}, \mathrm{CDCl}_{3}\right) 156.08(\mathrm{C} 7)$, 145.74 (C8b), 139.28 (C4a), $134.79\left(\mathrm{C} 1{ }^{\prime}\right), 128.72$ (C3'), 127.98 (C4'), 127.81 (C2'), 122.12 (C5), 121.08 (C8a), 108.35 (C6), $76.50(\mathrm{C} 1), 70.71\left(\mathrm{OCH}_{2}\right), 55.91\left(\mathrm{OCH}_{3}\right), 41.82(\mathrm{C} 2 \mathrm{a})$, 35.72 (C4), 35.57 (C3), 31.87 (C8), 29.90 (C2); (+)-LRESIMS ${ }_{50} \mathrm{~m} / \mathrm{z} 317 \quad[\mathrm{M}+\mathrm{Na}]^{+}$; (+)-HRESIMS $\mathrm{m} / \mathrm{z} \quad 317.1511, \mathrm{C}_{20} \mathrm{H}_{22} \mathrm{O}_{2}$ $[\mathrm{M}+\mathrm{Na}]^{+}$requires 317.1512 .

\section{1-(4'-Chlorobenzyloxy)-7-methoxy-1,2,2a,3,4,8-} hexahydrocyclopenta[cd]azulene (21b)

White solid; $34.4 \mathrm{mg}(89.1 \%)$; $\mathrm{mp} 78-80{ }^{\circ} \mathrm{C} ; v_{\max }\left(\mathrm{cm}^{-1}\right) 3010$ $55(\mathrm{ArH}), 2835\left(\mathrm{CH}_{2}\right), 1485\left(\mathrm{CH}_{2}\right), 1245\left(\mathrm{OCH}_{3}\right) ; \delta_{\mathrm{H}}(500 \mathrm{MHz}$, $\left.\mathrm{CDCl}_{3}\right) 7.35(\mathrm{~m}, 4 \mathrm{H}, \mathrm{PhH}), 7.02(\mathrm{~d}, J=8.0 \mathrm{~Hz}, 1 \mathrm{H}, \mathrm{H}-5), 6,62$ (d, $J=8.0 \mathrm{~Hz}, 1 \mathrm{H}, \mathrm{H}-5), 4.66\left(\mathrm{q}, J=12.5 \mathrm{~Hz}, 2 \mathrm{H}, \mathrm{OCH}_{2}\right)$, $3.91(\mathrm{~m}, 1 \mathrm{H}, \mathrm{H}-1), 3.82\left(\mathrm{~s}, 3 \mathrm{H}, \mathrm{OCH}_{3}\right), 3.27$ (dd, $J=6.0,17.0$ $\mathrm{Hz}, 1 \mathrm{H}, \mathrm{H}-2), 2.94(\mathrm{~m}, 1 \mathrm{H}, \mathrm{H}-2 \mathrm{a}), 2.84(\mathrm{~m}, 1 \mathrm{H}, \mathrm{H}-8), 2.73$ $60\left(\mathrm{dd}, J=8.5,15.2 \mathrm{~Hz}, 1 \mathrm{H}, \mathrm{H}^{\prime}-8\right), 2.49(\mathrm{dd}, J=9.5,17.5 \mathrm{~Hz}$, $\left.1 \mathrm{H}, \mathrm{H}^{\prime}-2\right), 2.44$ (dt, $\left.J=3.7,11.0 \mathrm{~Hz}, 1 \mathrm{H}, \mathrm{H}-4\right), 2.31$ (pent, $J$ $\left.=6.0 \mathrm{~Hz}, 1 \mathrm{H}, \mathrm{H}^{\prime}-4\right), 1.64(\mathrm{~m}, 1 \mathrm{H}, \mathrm{H}-3), 1.38(\mathrm{q}, J=7.6 \mathrm{~Hz}$, $\left.1 \mathrm{H}, \mathrm{H}^{\prime}-3\right) ; \delta_{\mathrm{C}}\left(125 \mathrm{MHz}, \mathrm{CDCl}_{3}\right) 156.06(\mathrm{C} 7), 145.66(\mathrm{C} 8 \mathrm{~b})$, 137.83 (C4a), 134.79 (C1'), 133.54 (C4'), 129.23 (C2'), 128.87 65 (C3'), 122.18 (C5), 120.88 (C8a), 108.37 (C6), 76.55 (C1), $69.95\left(\mathrm{OCH}_{2}\right), 55.90\left(\mathrm{OCH}_{3}\right), 41.77(\mathrm{C} 2 \mathrm{a}), 35.71(\mathrm{C} 4), 35.56$ (C3), 31.87 (C8), 29.88 (C2); (+)-LRESIMS $\mathrm{m} / \mathrm{z} \quad 351$ $[\mathrm{M}+\mathrm{Na}]^{+}$; (+)-HRESIMS $\mathrm{m} / \mathrm{z} 351.1110, \mathrm{C}_{20} \mathrm{H}_{21} \mathrm{ClO}_{2}[\mathrm{M}+\mathrm{Na}]^{+}$ requires 351.1123 .

\section{1-(4'-Fluorobenzyloxy)-7-methoxy-1,2,2a,3,4,8- hexahydrocyclopenta[cd]azulene (21c)}

White solid, $26.9 \mathrm{mg}(73.2 \%) ; \mathrm{mp} 47-50{ }^{\circ} \mathrm{C} ; v_{\max }\left(\mathrm{cm}^{-1}\right) 3010$ $(\mathrm{ArH}), 2835\left(\mathrm{CH}_{2}\right), 1485\left(\mathrm{CH}_{2}\right), 1245\left(\mathrm{OCH}_{3}\right) ; \delta_{\mathrm{H}}(500 \mathrm{MHz}$, $\left.\mathrm{CDCl}_{3}\right) 7.38(\mathrm{~m}, 2 \mathrm{H}, \mathrm{PhH}), 7.03(\mathrm{~m}, 3 \mathrm{H}, \mathrm{PhH}, \mathrm{H}-5), 6.63$ (d, J $75=8.0 \mathrm{~Hz}, \mathrm{H}-6), 4.66\left(\mathrm{q}, J=12.5 \mathrm{~Hz}, 2 \mathrm{H}, \mathrm{OCH}_{2}\right), 3.92(\mathrm{~m}, 1 \mathrm{H}$, $\mathrm{H}-1), 3.82\left(\mathrm{~s}, 3 \mathrm{H}, \mathrm{OCH}_{3}\right), 3.29(\mathrm{dd}, J=6.5,17.0 \mathrm{~Hz}, 1 \mathrm{H}, \mathrm{H}-$ 2), $2.94(\mathrm{~m}, 1 \mathrm{H}, \mathrm{H}-2 \mathrm{a}), 2.85(\mathrm{~m}, 1 \mathrm{H}, \mathrm{H}-8), 2.74$ (dd, $J=8.0$ $\left.\mathrm{Hz}, 15.0 \mathrm{~Hz}, \mathrm{H}^{\prime}-8\right), 2.51$ (dd, $\left.J=9.5,17.0 \mathrm{~Hz}, \mathrm{H}^{\prime}-2\right), 2.43$ (dt, $J=4.0,11.5 \mathrm{~Hz}, \mathrm{H}-4), 2.31$ (pent, $\left.J=6.1 \mathrm{~Hz}, 1 \mathrm{H}, \mathrm{H}^{\prime}-4\right), 1.63$ $80(\mathrm{~m}, 1 \mathrm{H}, \mathrm{H}-3), 1.39\left(\mathrm{q}, J=11.6 \mathrm{~Hz}, 1 \mathrm{H}, \mathrm{H}^{\prime}-3\right) ; \delta_{\mathrm{C}}(125 \mathrm{MHz}$, $\left.\mathrm{CDCl}_{3}\right) 163.51$ and $161.56\left(\mathrm{C}^{\prime}\right), 155.96(\mathrm{C} 7), 145.57(\mathrm{C} 8 \mathrm{~b})$, $134.90(\mathrm{C} 4 \mathrm{a}), 134.93$ and $134.68\left(\mathrm{C} 1^{\prime}\right), 129.58$ and 129.52 (C2'), 122.07 (C5), 120.83 (C8a), 115.53 and 115.36 (C3'), 108.25 (C6), $76.52(\mathrm{C} 1), 69.93\left(\mathrm{OCH}_{2}\right), 55.70\left(\mathrm{OCH}_{3}\right), 41.69$ 85 (C2a), 35.62 (C4), 35.29 (C3), 31.76 (C8), 29.79 (C2); (+)-

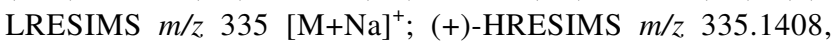
$\mathrm{C}_{20} \mathrm{H}_{21} \mathrm{FO}_{2}[\mathrm{M}+\mathrm{Na}]^{+}$requires 335.1418.

\section{General procedure for the synthesis of compounds 21d-e}

A solution of $20 \mathrm{a}(25 \mathrm{mg}, 0.12 \mathrm{mmol})$ in dry DMF $(0.5 \mathrm{~mL})$ 90 was added slowly to a $2 \mathrm{~mL}$ microwave process vial equipped with a stirrer bar and containing a cooled suspension of sodium hydride ( $60 \%$ dispersion in oil, $15 \mathrm{mg}, 0.36 \mathrm{mmol}$ ) in dry DMF $(1.0 \mathrm{~mL})$. Following complete addition, the reaction mixture was stirred at ambient temperature for $1 \mathrm{~h}$ under 95 argon prior to addition of alkyl bromide $(0.25 \mathrm{mmol})$. The mixture was subsequently heated in a microwave reactor at $110-115{ }^{\circ} \mathrm{C}$ for $45 \mathrm{~min}$. The reaction mixture was quenched with brine $(3 \mathrm{~mL})$ and extracted with ethyl acetate $(4 \times 2 \mathrm{~mL})$. The organic extracts were washed with brine $(3 \mathrm{~mL})$, dried 100 over anhydrous sodium sulfate, filtered and concentrated at reduced pressure. The crude oil was purified on silica gel (hexane:ethyl acetate, $98: 2 \rightarrow 99: 1$ ) to obtain the desired ethers as colourless oils in yields ranging from $52-55 \%$.

\section{1-Butoxy-7-methoxy-1,2,2a,3,4,8-}

\section{5 hexahydrocyclopenta[cd]azulene (21d)}

Colourless oil; $17.6 \mathrm{mg}$ (55\%); $v_{\max }\left(\mathrm{cm}^{-1}\right) 3010(\mathrm{ArH}), 2940$ $(\mathrm{CH}), 1620(\mathrm{C}=\mathrm{C}), 1485\left(\mathrm{CH}_{2}\right), 1245\left(\mathrm{OCH}_{3}\right) ; \delta_{\mathrm{H}}(500 \mathrm{MHz}$, $\left.\mathrm{CDCl}_{3}\right) 7.01(\mathrm{~d}, J=8.0 \mathrm{~Hz}, 1 \mathrm{H}, \mathrm{H}-5), 6.61(\mathrm{~d}, J=8.0 \mathrm{~Hz}, 1 \mathrm{H}$, $\mathrm{H}-6)$, 3.81-3.75 (m, 4H, OCH $3, \mathrm{H}-1), 3.61\left(\mathrm{~m}, 2 \mathrm{H}, \mathrm{OCH}_{2}\right)$, $1103.23(\mathrm{dd}, J=6.5,19.0 \mathrm{~Hz}, 1 \mathrm{H}, \mathrm{H}-2), 2.94(\mathrm{~m}, 1 \mathrm{H}, \mathrm{H}-2 \mathrm{a}), 2.84$ (m, 1H, H-8), 2.72 (dd, J = 7.5, $\left.14.7 \mathrm{~Hz}, \mathrm{H}^{\prime}-8\right), 2.39$ (m, 2H, H-4, H'-2), 2.30 (pent, $\left.J=6.1 \mathrm{~Hz}, 1 \mathrm{H}, \mathrm{H}^{\prime}-4\right), 1.61(\mathrm{~m}, 3 \mathrm{H}$, 
$\left.\mathrm{OCH}_{2} \mathrm{CH}_{2}, \mathrm{H}-3\right), 1.42\left(\mathrm{~m}, 2 \mathrm{H}, \mathrm{CH}_{2} \mathrm{CH}_{3}\right), 1.30(\mathrm{q}, J=11.6 \mathrm{~Hz}$, $\left.1 \mathrm{H}, \mathrm{H}^{\prime}-3\right), 0.95\left(\mathrm{t}, J=7.2 \mathrm{~Hz}, 3 \mathrm{H}, \mathrm{CH}_{2} \mathrm{CH}_{3}\right) ; \delta_{\mathrm{C}}(125 \mathrm{MHz}$, $\left.\mathrm{CDCl}_{3}\right) 155.90(\mathrm{C} 7), 145.60(\mathrm{C} 8 \mathrm{~b}), 134.58(\mathrm{C} 4 \mathrm{a}), 121.83$ (C5), 121.06 (C8a), 108.31 (C6), $76.86(\mathrm{C} 1), 68.55\left(\mathrm{OCH}_{2}\right)$, ${ }_{5} 55.70\left(\mathrm{OCH}_{3}\right), 41.70(\mathrm{C} 2 \mathrm{a}), 35.66(\mathrm{C} 4), 35.37(\mathrm{C} 3), 32.45$ $\left(\mathrm{OCH}_{2} \mathrm{CH}_{2}\right), 31.66(\mathrm{C} 8), 29.73(\mathrm{C} 2), 19.60\left(\mathrm{CH}_{2} \mathrm{CH}_{3}\right), 14.10$ $\left(\mathrm{CH}_{2} \mathrm{CH}_{3}\right)$; (+)-LRESIMS $\mathrm{m} / \mathrm{z} 283[\mathrm{M}+\mathrm{Na}]^{+}$; (+)-HRESIMS $\mathrm{m} / \mathrm{z}$ 283.1663, $\mathrm{C}_{17} \mathrm{H}_{24} \mathrm{O}_{2}[\mathrm{M}+\mathrm{Na}]^{+}$requires 283.1668.

\section{1-(Isopentyloxy)-7-methoxy-1,2,2a,3,4,8-}

10 hexahydrocyclopenta[cd]azulene (21e)

Colourless oil; $17.5 \mathrm{mg}$ (52.2\%); $v_{\max }\left(\mathrm{cm}^{-1}\right) 3010(\mathrm{ArH})$, $2950(\mathrm{CH}), 1620(\mathrm{C}=\mathrm{C}), 1485\left(\mathrm{CH}_{2}\right), 1245\left(\mathrm{OCH}_{3}\right) ; \delta_{\mathrm{H}}(500$ $\left.\mathrm{MHz}, \mathrm{CDCl}_{3}\right) 7.01(\mathrm{~d}, J=8.0 \mathrm{~Hz}, 1 \mathrm{H}, \mathrm{H}-5), 6.60$ (d, $J=8.0$ $\mathrm{Hz}, 1 \mathrm{H}, \mathrm{H}-6), 3.81\left(\mathrm{~m}, 4 \mathrm{H}, \mathrm{OCH}_{3}, \mathrm{H}-1\right), 3.61\left(\mathrm{~m}, 2 \mathrm{H}, \mathrm{OCH}_{2}\right)$, 153.23 (dd, $J=6.5,17.0 \mathrm{~Hz}, \mathrm{H}-2), 2.94$ (m, 1H, H-2a), 2.84 (m, $1 \mathrm{H}, \mathrm{H}-8), 2.72$ (dd, $\left.J=7.5,15.0 \mathrm{~Hz}, \mathrm{H}^{\prime}-8\right), 2.38$ (m, 2H, H-4, $\mathrm{H}^{\prime}-2$ ), 2.30 (pent, $\left.J=6.0 \mathrm{~Hz}, 1 \mathrm{H}, \mathrm{H}^{\prime}-4\right), 1.75(\mathrm{~m}, 1 \mathrm{H}$, $\left.\mathrm{C} H\left(\mathrm{CH}_{3}\right)_{2}\right), 1.63(\mathrm{~m}, 1 \mathrm{H}, \mathrm{H}-3), 1.52(\mathrm{q}, J=6.8 \mathrm{~Hz}, 2 \mathrm{H}$, $\left.\mathrm{OCH}_{2} \mathrm{CH}_{2}\right), 1.30$ (q, $\left.J=11.6 \mathrm{~Hz}, 1 \mathrm{H}, \mathrm{H}^{\prime}-3\right), 0.93$ (d, $J=6.5$ $\left.{ }_{20} \mathrm{~Hz}, 6 \mathrm{H}, \mathrm{CH}\left(\mathrm{CH}_{3}\right)_{2}\right) ; \delta_{\mathrm{C}}\left(125 \mathrm{MHz}, \mathrm{CDCl}_{3}\right) 155.90(\mathrm{C} 7), 145$ (C8b), 134.58 (4a), 121.84 (C5), 121.07 (C8a), 108.13 (C6), $76.89(\mathrm{C} 1), 67.17\left(\mathrm{OCH}_{2}\right), 55.70\left(\mathrm{OCH}_{3}\right), 41.70(\mathrm{C} 2 \mathrm{a}), 39.19$ $\left(\mathrm{OCH}_{2} \mathrm{CH}_{2}\right), 35.65(\mathrm{C} 4), 35.37(\mathrm{C} 3), 31.67(\mathrm{C} 8), 29.74(\mathrm{C} 2)$, $25.33(\mathrm{CH}), 22.85\left(\mathrm{CH}\left(\mathrm{CH}_{3}\right)_{2}\right) ; \quad(+)$-LRESIMS $\mathrm{m} / \mathrm{z} 297$ $25[\mathrm{M}+\mathrm{Na}]^{+} ;(+)$-HRESIMS $m / z$ 297.1824, $\mathrm{C}_{18} \mathrm{H}_{26} \mathrm{O}_{2}[\mathrm{M}+\mathrm{Na}]^{+}$ requires 297.1825.

\section{1-(Prop-2'-ynyloxy)-7-methoxy-1,2,2a,3,4,8-} hexahydrocyclopenta[cd]azulene (21f)

A solution of $20 \mathrm{a}(100 \mathrm{mg}, 0.12 \mathrm{mmol})$ in dry THF $(1.0 \mathrm{~mL})$ 30 was added slowly to a stirred and cooled suspension sodium hydride (60\% dispersion in oil, $79 \mathrm{mg}, 1.96 \mathrm{mmol}$ ) in dry THF $(1.2 \mathrm{~mL})$. Upon complete addition, the reaction mixture was stirred at ambient temperature for $1 \mathrm{~h}$ under argon. Propargyl bromide (233 mg, $1.96 \mathrm{mmol}$ ) was then added and the mixture 35 stirred for an additional $40 \mathrm{~h}$ at $55{ }^{\circ} \mathrm{C}$ under argon. The reaction mixture was quenched with brine $(3 \mathrm{~mL})$ and extracted with ethyl acetate $(4 \times 2 \mathrm{~mL})$. The organic extract was washed with brine $(3 \mathrm{~mL})$, dried over anhydrous sodium sulfate, filtered and concentrated at reduced pressure. The 40 crude oil was purified on silica gel (hexane:ethyl acetate, 98:2) to obtain the title compound as a yellow oil (62 mg, $65 \%$ after recovery of $20 \mathrm{mg}$ of unreacted starting material): $v_{\max }\left(\mathrm{cm}^{-1}\right) 3285(\mathrm{CC}-\mathrm{H}), 3010(\mathrm{ArH}), 2940(\mathrm{CH}), 1620$ $(\mathrm{C}=\mathrm{C}), 1485\left(\mathrm{CH}_{2}\right), 1245\left(\mathrm{OCH}_{3}\right), 670(\mathrm{CC}-\mathrm{H}) ; \delta_{\mathrm{H}}(500 \mathrm{MHz}$, $\left.{ }_{45} \mathrm{CDCl}_{3}\right) 7.02(\mathrm{~d}, J=8.0 \mathrm{~Hz}, 1 \mathrm{H}, \mathrm{H}-5), 6.61(\mathrm{~d}, J=8.0 \mathrm{~Hz}, 1 \mathrm{H}$, $\mathrm{H}-6), 4.37-4.30\left(\mathrm{~m}, 2 \mathrm{H}, \mathrm{OCH}_{2}\right), 4.06(\mathrm{~m}, 1 \mathrm{H}, \mathrm{H}-1), 3.80$ (s, $\left.3 \mathrm{H}, \mathrm{OCH}_{3}\right), 3.26(\mathrm{dd}, J=6.5,17.0 \mathrm{~Hz}, 1 \mathrm{H}, \mathrm{H}-2), 2.97$ (hept, $J$ $=5.6 \mathrm{~Hz}, 1 \mathrm{H}, \mathrm{H}-2 \mathrm{a}), 2.85(\mathrm{~m}, 1 \mathrm{H}, \mathrm{H}-8), 2.73(\mathrm{dd}, J=7.5$, $\left.15.2 \mathrm{~Hz}, 1 \mathrm{H}, \mathrm{H}^{\prime}-8\right), 2.45-2.39$ (m, 3H, $\left.\mathrm{CH}_{2} \mathrm{CCH}, \mathrm{H}^{\prime}-2, \mathrm{H}-4\right)$, 502.32 (pent, $\left.J=6.1 \mathrm{~Hz}, \mathrm{H}^{\prime}-4\right), 1.63(\mathrm{~m}, 1 \mathrm{H}, \mathrm{H}-3), 1.33$ (q, $J=$ $\left.8.7 \mathrm{~Hz}, 1 \mathrm{H}, \mathrm{H}^{\prime}-3\right) ; \delta_{\mathrm{C}}\left(125 \mathrm{MHz}, \mathrm{CDCl}_{3}\right) 155.85(\mathrm{C} 7), 145.37$ (C8b), 134.54 (4a), 121.99 (C5), 120 (C8a), 108.17 (C6), $80.40\left(\mathrm{CH}_{2} \mathrm{CCH}\right), 75.94(\mathrm{C} 1), 74.11\left(\mathrm{CH}_{2} \mathrm{CCH}\right), 55.77\left(\mathrm{OCH}_{2}\right)$, $55.69\left(\mathrm{OCH}_{3}\right), 41.49(\mathrm{C} 2 \mathrm{a}), 35.34(\mathrm{C} 4), 35.21(\mathrm{C} 3), 31.66$ 55 (C8), 29.31 (C2); (+)-LRESIMS $\mathrm{m} / z, 265 \quad[\mathrm{M}+\mathrm{Na}]^{+} ;$(+)HRESIMS $m / z \quad 265.1195, \quad \mathrm{C}_{16} \mathrm{H}_{18} \mathrm{O}_{2} \quad[\mathrm{M}+\mathrm{Na}]^{+}$requires 265.1199 .
1'-Benzyl-4'-((-7-methoxy-1,2,2a,3,4,8-

hexahydrocyclopenta[cd] azulen-1-yloxy)methyl)-1H-1',2',3'${ }_{60}$ triazole (23a)

To a stirred suspension of $21 \mathrm{f}$ ( $40 \mathrm{mg}, 0.17 \mathrm{mmol}$ ), benzyl azide $(26.4 \mathrm{mg}, 0.2 \mathrm{mmol})$ and sodium ascorbate $(20 \mathrm{~mol} \%)$ in solution of $t$-butanol $(0.5 \mathrm{~mL})$, water $(0.5 \mathrm{~mL})$ and ethanol $(0.5 \mathrm{~mL})$ was added copper sulfate pentahydrate $(5 \mathrm{~mol} \%)$. ${ }_{65}$ The reaction mixture stirred at room temperature for $16 \mathrm{~h}$ then diluted with brine $(3 \mathrm{~mL})$ and extracted with ethyl acetate $(4 \times$ $3 \mathrm{~mL}$ ). The organic extracts were dried over anhydrous sodium sulfate, filtered and concentrated at reduced pressure to afford the crude product. Silica gel chromatography 70 (hexane:ethyl acetate, $85: 15 \rightarrow 80: 20$ ) afforded the title compound as a white solid $(37 \mathrm{mg}, 60 \%)$ : $\mathrm{mp} 78-82{ }^{\circ} \mathrm{C} ; v_{\max }$ $\left(\mathrm{cm}^{-1}\right) 2940(\mathrm{CH}), 1615(\mathrm{~N}=\mathrm{N}), 1485\left(\mathrm{CH}_{2}\right), 1245\left(\mathrm{OCH}_{3}\right) ; \delta_{\mathrm{H}}$ $\left(500 \mathrm{MHz}, \mathrm{CDCl}_{3}\right) 7.48(\mathrm{~s}, 1 \mathrm{H}, \mathrm{H}-5$ '), 7.40-7.34 (m, 3H, $\mathrm{PhH}), 7.28(\mathrm{~d}, J=7.0 \mathrm{~Hz}, 2 \mathrm{H}, \mathrm{PhH}), 7.00(\mathrm{~d}, J=8.0 \mathrm{~Hz}, 1 \mathrm{H}$, $75 \mathrm{H} 5), 6.59$ (d, $J=8.0 \mathrm{~Hz}, 1 \mathrm{H}, \mathrm{H} 6), 5.52$ (s, 2H, N-CH $), 4.82-$ $4.76\left(\mathrm{~m}, 2 \mathrm{H}, \mathrm{OCH}_{2}\right), 3.95(\mathrm{~m}, 1 \mathrm{H}, \mathrm{H}-1), 3.79\left(\mathrm{~s}, 3 \mathrm{H}, \mathrm{OCH}_{3}\right)$, $3.24(\mathrm{dd}, J=6.0,17.2 \mathrm{~Hz}, \mathrm{H}-2), 2.92(\mathrm{~m}, 1 \mathrm{H}, \mathrm{H}-2 \mathrm{a}), 2.82(\mathrm{~m}$, $1 \mathrm{H}, \mathrm{H}-8), 2.71$ (dd, $\left.J=8.0,15.0 \mathrm{~Hz}, 1 \mathrm{H}, \mathrm{H}^{\prime}-8\right), 2.46$ (m, $2 \mathrm{H}$, H'-2, H-4), 2.29 (5, J = 6.1 Hz, 1H, H'-4), 1.60 (m, 1H, H-3), 801.30 (q, $\left.J=13.5 \mathrm{~Hz}, 1 \mathrm{H}, \mathrm{H}^{\prime}-3\right)$; $\delta_{\mathrm{C}}\left(125 \mathrm{MHz}, \mathrm{CDCl}_{3}\right) 155.82$ (C7), 145.41 (C8b), 134.78 (C4a), 134.54 (C1"), 129.25 (C4"), 128.88 (C3"), 128.29 (C2"), 122.35 (C5'), 121.94 (C5), 120.63 (C8a), 108.14 (C6), 77.41 (C4'), 76.86 (C1), 62.40 $\left(\mathrm{OCH}_{2}\right), 55.67\left(\mathrm{OCH}_{3}\right), 54.34\left(\mathrm{~N}-\mathrm{CH}_{2}\right), 41.48(\mathrm{C} 2 \mathrm{a}), 35.31$ 85 (C4), 35.31 (C3), 31.64 (C8), 29.66 (C2); (+)-LRESIMS m/z $398[\mathrm{M}+\mathrm{Na}]^{+} ; \quad(+)$-HRESIMS $m / z \quad 398.1825, \quad \mathrm{C}_{23} \mathrm{H}_{25} \mathrm{~N}_{3} \mathrm{O}_{2}$ $[\mathrm{M}+\mathrm{Na}]^{+}$requires 398.1838 .

\section{General procedure for the synthesis of compounds $23 \mathrm{~b}-\mathrm{c}$}

Copper sulfate solution $(1 \mathrm{M}, 0.5 \mathrm{~mL})$ was added to a $2 \mathrm{~mL}$ 90 microwave process vial equipped with stirrer bar and containing $21 f$ ( $35.0 \mathrm{mg}, 0.14 \mathrm{mmol}$ ), alkyl bromide, sodium azide $(10.4 \mathrm{mg}, 0.16 \mathrm{mmol})$ and copper powder $(8 \mathrm{mg})$ in $t$ butanol $(0.8 \mathrm{~mL})$. The reaction vessel was sealed and the mixture was heated in a microwave reactor at $110{ }^{\circ} \mathrm{C}$ for 20 $95 \mathrm{~min}$. The reaction mixture was quenched with brine $(3 \mathrm{~mL})$ and extracted with ethyl acetate $(4 \times 3 \mathrm{~mL})$. The organic solvent was washed with brine $(4 \mathrm{~mL})$, dried over anhydrous sodium sulfate, filtered and concentrated at reduced pressure to afford an oil. The crude product was purified on silica gel 100 (hexane:ethyl acetate, $85: 15 \rightarrow 80: 20$ ) to obtain the title compounds as white solids in $42-45 \%$ yield.

\section{1'-Butyl-4'-((-7-methoxy-1,2,2a,3,4,8-}

hexahydrocyclopenta[cd]azulen-1-yloxy)methyl)-1H-1',2',3'triazole (23b)

105 White solid; $20.9 \mathrm{mg}(44.8 \%) ; 90-92{ }^{\circ} \mathrm{C} ; v_{\max }\left(\mathrm{cm}^{-1}\right) 2940$ $(\mathrm{CH}), 1615(\mathrm{~N}=\mathrm{N}), 1485\left(\mathrm{CH}_{2}\right), 1245\left(\mathrm{OCH}_{3}\right) ; \delta_{\mathrm{H}}(500 \mathrm{MHz}$, $\left.\mathrm{CDCl}_{3}\right) 7.5$ (s, 1H, H-5'); 7.01 (d, $\left.J=8.0 \mathrm{~Hz}, 1 \mathrm{H}, \mathrm{H}-5\right), 6.60$ $(\mathrm{d}, J=8.0 \mathrm{~Hz}, 1 \mathrm{H}, \mathrm{H}-6), 4.81\left(\mathrm{q}, J=10.0 \mathrm{~Hz}, 2 \mathrm{H}, \mathrm{N}-\mathrm{CH}_{2}\right)$, $4.35\left(t, J=7.2 \mathrm{~Hz}, 2 \mathrm{H}, \mathrm{OCH}_{2}\right), 3.95(\mathrm{~m}, 1 \mathrm{H}, \mathrm{H}-1), 3.80(\mathrm{~s}$, $\left.1103 \mathrm{H}, \mathrm{OCH}_{3}\right), 3.26(\mathrm{dd}, J=6.0,17.0 \mathrm{~Hz}, 1 \mathrm{H}, \mathrm{H}-2), 2.94(\mathrm{~m}, 1 \mathrm{H}$, H-2a), 2.84 (m, 1H, H-8), 2.72 (dd, $J=8.0,14.7 \mathrm{~Hz}, 1 \mathrm{H}, \mathrm{H}^{\prime}-$ 8), 2.45 (m, 2H, H'-2, H-4), $2.30\left(5, J=6.2 \mathrm{~Hz}, 1 \mathrm{H}, \mathrm{H}^{\prime}-4\right)$, $1.90\left(\mathrm{~m}, 2 \mathrm{H}, \mathrm{NCH}_{2} \mathrm{CH}_{2}\right), 1.61(\mathrm{~m}, 1 \mathrm{H}, \mathrm{H}-3), 1.36(\mathrm{~m}, 3 \mathrm{H}$, 
$\left.\mathrm{CH}_{2} \mathrm{CH}_{3}, \mathrm{H}^{\prime}-3\right), 0.96\left(\mathrm{t}, J=7.2 \mathrm{~Hz}, 3 \mathrm{H}, \mathrm{CH}_{2} \mathrm{CH}_{3}\right) ; \delta_{\mathrm{C}}(125$ $\left.\mathrm{MHz}, \mathrm{CDCl}_{3}\right) 155.86(\mathrm{C} 7), 146.10(\mathrm{C} 4), 145.47(\mathrm{C} 8 \mathrm{~b})$, 134.59 (C4a), 122.20 (C5'), 121.97 (C5), 120.70 (C8a), 108.17 (C6), $76.79(\mathrm{C} 1), 62.49\left(\mathrm{OCH}_{2}\right), 55.71\left(\mathrm{OCH}_{3}\right), 50.21$ ${ }_{5}\left(\mathrm{NCH}_{2}\right), \quad 41.53(\mathrm{C} 2 \mathrm{a}), \quad 35.37 \quad(\mathrm{C} 4), \quad 35.32 \quad(\mathrm{C} 3), \quad 32.43$ $\left(\mathrm{NCH}_{2} \mathrm{CH}_{2}\right), 31.68(\mathrm{C} 8), 29.73(\mathrm{C} 2), 19.90\left(\mathrm{CH}_{2} \mathrm{CH}_{3}\right), 13.60$ $\left(\mathrm{CH}_{2} \mathrm{CH}_{3}\right) ;$ (+)-LRESIMS $\mathrm{m} / z 364[\mathrm{M}+\mathrm{Na}]^{+} ;$(+)-HRESIMS $m / z$ 364.1997, $\mathrm{C}_{20} \mathrm{H}_{27} \mathrm{~N}_{3} \mathrm{O}_{2}[\mathrm{M}+\mathrm{Na}]^{+}$requires 364.1995.

\section{1 '-Isopentyl-4' -((-7-methoxy-1,2,2a,3,4,8-}

10 hexahydrocyclopenta[cd]azulen-1-yloxy)methyl)-1H-1',2',3'triazole (23c)

White solid: $23.1 \mathrm{mg}(42.4 \%) ; \mathrm{mp} 88-90{ }^{\circ} \mathrm{C} ; v_{\max }\left(\mathrm{cm}^{-1}\right) 2950$ $(\mathrm{CH}), 1615(\mathrm{~N}=\mathrm{N}), 1485\left(\mathrm{CH}_{2}\right), 1245\left(\mathrm{OCH}_{3}\right) ; \delta_{\mathrm{H}}(500 \mathrm{MHz}$, $\left.\mathrm{CDCl}_{3}\right) 7.55$ (s, 1H, H-5'), 7.01-6.99 (d, $\left.J=8.0 \mathrm{~Hz}, 1 \mathrm{H}, \mathrm{H}-5\right)$, $156.61(\mathrm{~d}, J=8.0 \mathrm{~Hz}, 1 \mathrm{H}, \mathrm{H}-6), 4.42(\mathrm{q}, J=10.0 \mathrm{~Hz}, 2 \mathrm{H}, \mathrm{N}-$ $\left.\mathrm{CH}_{2}\right), 4.37\left(\mathrm{t}, \mathrm{J}=7.7 \mathrm{~Hz}, 2 \mathrm{H}, \mathrm{OCH}_{2}\right), 3.96(\mathrm{~m}, 1 \mathrm{H}, \mathrm{H}-1), 3.80$ (s, $\left.3 \mathrm{H}, \mathrm{OCH}_{3}\right), 3.26(\mathrm{dd}, J=6.0,17.0 \mathrm{~Hz}, 1 \mathrm{H}, \mathrm{H}-2), 2.94(\mathrm{~m}$, $1 \mathrm{H}, \mathrm{H}-2 \mathrm{a}), 2.83(\mathrm{~m}, 1 \mathrm{H}, \mathrm{H}-8), 2.72(\mathrm{dd}, J=8.0,15.0 \mathrm{~Hz}, 1 \mathrm{H}$, H'-8), 2.44 (m, 2H, H'-2, H-4), 2.30 (5, J = 6.1 Hz, 1H, H'-4), $201.81\left(\mathrm{~m}, 2 \mathrm{H}, \mathrm{CH}_{2} \mathrm{CH}_{2} \mathrm{CH}\right), 1.62\left(\mathrm{~m}, 2 \mathrm{H}, \mathrm{CH}_{2} \mathrm{CH}, \mathrm{H}-3\right), 1.33$ $\left(\mathrm{q}, J=11.6 \mathrm{~Hz}, 1 \mathrm{H}, \mathrm{H}^{\prime}-3\right) ; \delta_{\mathrm{C}}\left(125 \mathrm{MHz}, \mathrm{CDCl}_{3}\right) 155.84$ (C7), 146.11 (C4'), 145.45 (C8b), 134.57 (C4a), 122.11 (C5'), 121.95 (C5), 120.68 (C8a), 108.15 (C6), 76.76 (C1), 62.46 $\left(\mathrm{OCH}_{2}\right), 55.69\left(\mathrm{OCH}_{3}\right), 48.81\left(\mathrm{~N}-\mathrm{CH}_{2}\right), 41.51(\mathrm{C} 2 \mathrm{a}), 39.21$ $25\left(\mathrm{CH}_{2} \mathrm{CH}\right), 35.34(\mathrm{C} 4), 35.32(\mathrm{C} 3), 31.66(\mathrm{C} 8), 29.71(\mathrm{C} 2)$, $25.69 \quad\left(\mathrm{CH}_{2} \mathrm{CH}\right), \quad 22.34 \quad\left(\mathrm{CH}_{3}\right)_{2} ; \quad(+)$-LRESIMS $\mathrm{m} / \mathrm{z} \quad 378$ $[\mathrm{M}+\mathrm{Na}]^{+}, \quad 356 \quad[\mathrm{M}+\mathrm{H}]^{+}$; (+)-HRESIMS $\mathrm{m} / \mathrm{z} \quad 378.2136$, $\mathrm{C}_{21} \mathrm{H}_{29} \mathrm{~N}_{3} \mathrm{O}_{2}[\mathrm{M}+\mathrm{Na}]^{+}$requires 378.2152.

\section{Acknowledgements}

30 The authors acknowledge financial support of this work by Griffith University and the Eskitis Institute. We thank Hoan $\mathrm{Vu}$ from Griffith University for acquiring the HRESIMS data and the Australian Research Council for LIEF grants that enabled purchase of the NMR spectrometer (LE0668477) and ${ }_{35}$ FTMS (LE0237908) used in this work.

\section{Notes and references}

${ }^{a}$ Eskitis Institute, Griffith University, Nathan QLD 4111, Australia. Fax: +6173735 6001; Tel: +6173735 6041; E-mail:

david.camp@griffith.edu.au

$40 †$ Electronic Supplementary Information (ESI) available: ${ }^{1} \mathrm{H}$ and ${ }^{13} \mathrm{C}$ NMR spectra of all previously unreported compounds, i.e. 15, 16, 17, 20a-b, 21a-f, 23a-c. See DOI: 10.1039/b000000x/

1. R. S. Bohacek, C. McMartin and W. C. Guida, Med. Res. Rev., 1996, 16, 3 .

2. D. R. Spring, Org. Biomol. Chem., 2003, 1, 3867.

3. P. D. Leeson, A. M. Davis and J. Steele, Drug Discov. Today: Technol., 2004, 1, 189.

4. B. E. Evans, K. E. Rittle, M. G. Bock, R. M. DiPardo, R. M. Freidinger, W. L. Whitter, G. F. Lundell, D. F. Veber, P. S. Anderson, R. S. L. Chang, V. J. Lotti, D. J. Cerino, T. B. Chen, P. J. Kling, K. A. Kunkel, J. P. Springer and J. Hirshfieldt, J. Med. Chem., 1988, 31, 2235.

5. R. W. DeSimone, K. S. Currie, S. A. Mitchell, J. W. Darrow and

55 D. A. Pippin, Comb. Chem. High Throughput Screen., 2004, 7,
473.

6. J. G. Buta, J. L. Flippen and W. R. Lusby, J. Org. Chem., 1978, 43, 1002 .

7. N. Sun, Z. Xue, X. Liang and L. Huang, Acta. Pharm. Sin., 1979, 14, 39.

8. S. Kang, S. Cai and L. Teng, Acta. Pharm. Sin., 1981, 16, 867.

9. A. Quintas-Cardama and J. Cortes, Expert Opin. Pharmacother., 2008, 9, 1029.

10. E. A. Eisenhauer and J. B. Vermorken, Drugs, 1998, 55, 5.

65 11. D. G. I. Kingston, J. Nat. Prod., 2000, 63, 726.

12. B. M. Fraga, Nat. Prod. Rep., 1996, 13, 307.

13. M. Lautens, W. Klute and W. Tam, Chem. Rev., 1996, 96, 49.

14. M. E. Welsch, S. A. Snyder and B. R. Stockwell, Curr. Opin. Chem. Biol., 2010, 14, 347.

70 15. B. Frey, A. P. Wells, F. S. Roden, A. T.D., D. C. Hockless, A. C. Willis and L. N. Mander, Aust. J. Chem., 2000, 53, 819.

16. P. Willet, Drug Discov. Today, 2006, 11, 1046.

17. A. A. Shelat and R. K. Guy, Nat. Chem. Biol., 2007, 3, 442.

18. D. H. Rogers, J. C. Morris, F. S. Roden, B. Frey, G. R. King, F.-

75 W. Russkamp, R. A. Bell and L. N. Mander, Pure Appl. Chem., 1996, 68, 515.

19. B. Frey, A. P. Wells, D. H. Rogers and L. N. Mander, J. Am. Chem. Soc., 1998, 120, 1914.

20. F. Berardi, S. Ferorelli, N. A. Colabufo, M. Leopoldo, R. Perrone and V. Tortorella, Bioorg. Med. Chem., 2001, 9, 1325.

21. K. Fukatsu, O. Uchikawa, M. Kawada, T. Yamano, M. Yamashita, K. Kato, K. Hirai, S. Hinuma, M. Miyamoto and S. Ohkawa, J. Med. Chem., 2002, 45, 4212.

22. J. E. Hein and V. V. Fokin, Chem. Soc. Rev., 2010, 39, 1302.

85 23. P. Appukkuttan, W. Dehaen, V. V. Fokin and E. Van der Eycken, Org. Lett., 2004, 6, 4223.

24. I. D. Jenkins, F. Lacrampe, J. Ripper, L. Alcaraz, P. V. Le, G. Nikolakopoulos, P. d. A. Leone, R. H. White and R. J. Quinn, J. Org. Chem., 2009, 74, 1304.

90 25. V. M. Avery, D. Camp, A. R. Carroll, I. D. Jenkins and R. J. Quinn, in Comprehensive Natural Products II Chemistry and Biology, eds. L. N. Mander and H.-W. Lui, Elseiver, Oxford, 2010, pp. 177-203.

26. T. P. O'Sullivan, H. Zhang and L. N. Mander, Org. Biomol. Chem., 2007, 5, 2617.

27. L. Evanno, A. Deville, L. Dubost, A. Chiaroni, B. Bodoa and B. Naya, Tetrahedron Lett., 2007, 48, 2893.

28. H. E. Gottlieb, V. Kotlyar and A. Nudelman, J. Org. Chem., 1997, 62, 7512 .

100 29. U. Sanyal, P. K. Ghoshal and P. C. Dutta, Tetrahedron Lett., $1978,19,2187$ 